FLOODS OF JUNE 17, 1990, AND JULY 9, 1993, ALONG SQUAW CREEK AND THE SOUTH SKUNK RIVER IN AMES, IOWA, AND VICINITY

by Robert F. Einhellig and David A. Eash

U.S. GEOLOGICAL SURVEY

Open-File Report 96-249

Prepared in cooperation with the

IOWA HIGHWAY RESEARCH BOARD and the PROJECT DEVELOPMENT DIVISION of the IOWA DEPARTMENT OF TRANSPORTATION (IOWA DOT Research Project HR-140)

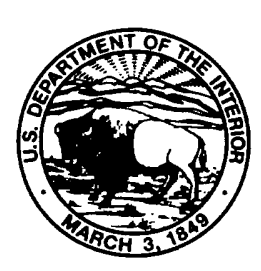

lowa City, lowa 


\section{U.S. DEPARTMENT OF THE INTERIOR BRUCE BABBITT, Secretary}

U.S. GEOLOGICAL SURVEY

GORDON P. EATON, Director

For additional information write to:

District Chief

U.S. Geological Survey, WRD

Water Resources Division

Room 269 Federal Building

400 South Clinton Street

lowa City, lowa 52244
Copies of this report can be purchased from:

U.S. Geological Survey

Earth Science Information Center Open-File Reports Section

Box 25286, Mail Stop 517

Denver Federal Center

Denver, Colorado 80225 


\section{CONTENTS}

Page

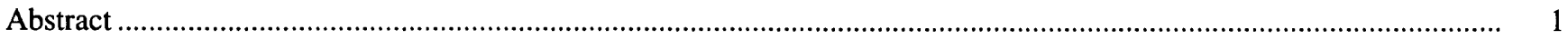

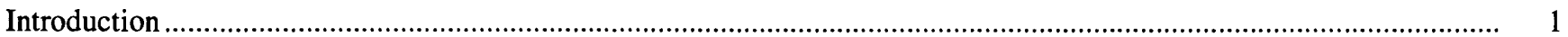

Purpose and scope

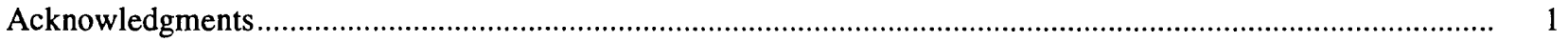

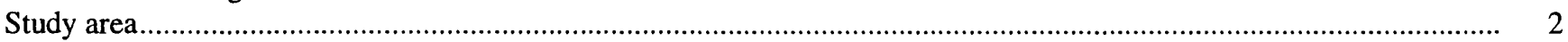

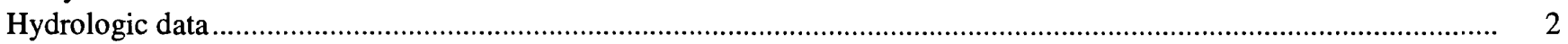

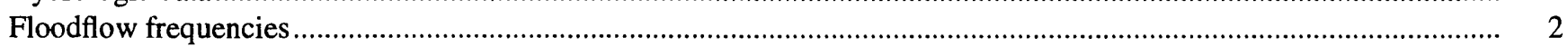

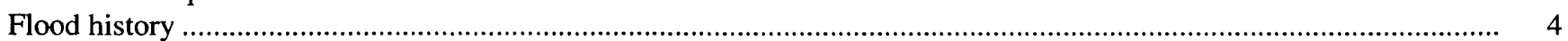

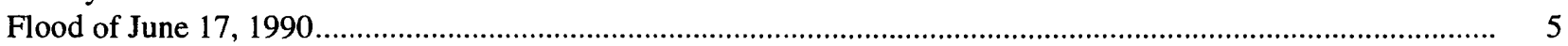

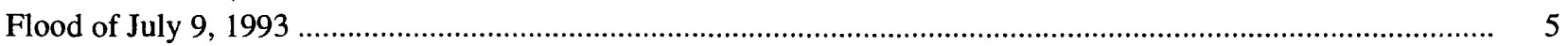

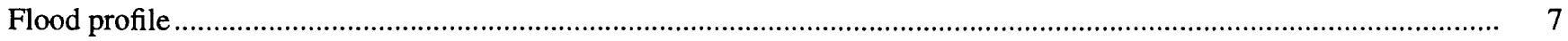

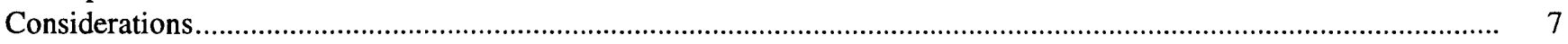

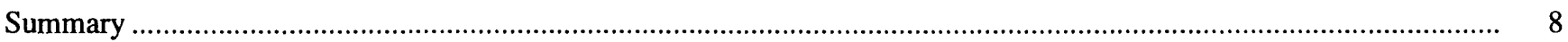

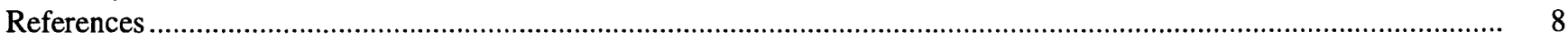

Appendix A. Peak stages and discharges for active streamflow-gaging stations along Squaw Creek and the

South Skunk River in Ames, Iowa, and vicinity 1918-94

Appendix B. Water-surface-elevation profiles for Squaw Creek and the South Skunk River

Appendix C. Descriptions and elevations of temporary bench marks and reference points in the Squaw Creek

and South Skunk River Basins in Ames, Iowa, and vicinity

\section{FIGURES}

1. Map showing profiled stream reaches, active U.S. Geological Survey streamflow-gaging stations, and selected roads in the study area

2. Graph showing water-surface-elevation profiles for Squaw Creek ................................................................... 27

3. Graphs showing water-surface-elevation profiles for South Skunk River ...................................................... 28

\section{TABLES}

1. Floodflow frequencies for active streamflow-gaging stations along Squaw Creek and the South Skunk River in Ames, Iowa, and vicinity .....

2. Selected flood-peak discharges, recurrence intervals, and unit runoff for active streamflow-gaging stations along Squaw Creek and the South Skunk River in Ames, Iowa, and vicinity. 
CONVERSION FACTORS, ABBREVIATIONS, AND VERTICAL DATUM

\begin{tabular}{|c|c|c|}
\hline Multiply & By & To obtain \\
\hline $\begin{array}{r}\text { inch (in.) } \\
\text { foot }(\mathrm{ft}) \\
\text { mile (mi) }\end{array}$ & $\begin{array}{l}25.4 \\
0.3048 \\
1.609\end{array}$ & $\begin{array}{l}\text { millimeter } \\
\text { meter } \\
\text { kilometer }\end{array}$ \\
\hline square mile $\left(\mathrm{mi}^{2}\right)$ & 2.590 & square kilometer \\
\hline $\begin{array}{l}\text { cubic foot per second }\left(\mathrm{ft}^{3} / \mathrm{s}\right) \\
\text { cubic foot per second per square } \\
\text { mile }\left[\left(\mathrm{ft}^{3} / \mathrm{s}\right) / \mathrm{mi}^{2}\right]\end{array}$ & $\begin{array}{l}0.02832 \\
0.01093\end{array}$ & $\begin{array}{l}\text { cubic meter per second } \\
\text { cubic meter per second per } \\
\text { square kilometer }\end{array}$ \\
\hline
\end{tabular}

Sea Level: In this report, "sea level" refers to the National Geodetic Vertical Datum of 1929--a geodetic datum derived from a general adjustment of the first-order level nets of the United States and Canada, formerly called Sea Level Datum of 1929. 


\title{
FLOODS OF JUNE 17, 1990, AND JULY 9, 1993, ALONG SQUAW CREEK AND THE SOUTH SKUNK RIVER IN AMES, IOWA, AND VICINITY
}

\author{
by Robert F. Einhellig and David A. Eash
}

\section{ABSTRACT}

Water-surface-elevation profiles and peak discharges for the floods of June 17, 1990, and July 9, 1993, along Squaw Creek and the South Skunk River, in Ames, Iowa, are presented in this report. The maximum flood-peak discharge of 24,300 cubic feet per second for the streamflowgaging station on Squaw Creek at Ames, Iowa (station number 05470500) occurred on July 9, 1993. This discharge was 80 percent larger than the 100-year recurrence-interval discharge and exceeded the previous record flood-peak discharge of June 17, 1990, by 94 percent. The July 9, 1993, flood-peak discharge of 26,500 cubic feet per second on the South Skunk River below Squaw Creek (station number 05471000) was also a peak of record, exceeding the previous record flood-peak discharge of June 27,1975 , by 80 percent, and the 100 -year recurrence-interval discharge by 60 percent. A flood history describes rainfall conditions for floods that occurred during 1990 and 1993.

\section{INTRODUCTION}

Evaluation of flood hazards and the planning, design, and operation of various structures on flood plains require information about floods. Flood reports supply specific information for selected floods and are used by planners and engineers to evaluate the magnitude and frequency of floods in a river basin.

\section{Purpose and Scope}

The City of Ames was established in Story County on the banks of Squaw Creek and the South Skunk River near their point of confluence in central
Iowa. Substantial reaches of both streams, as well as their confluence, are contained within the Ames municipal boundary. These two streams, either individually, or together, have been the source of flooding several times during Ames' history. None of these floods, hovever, can compare in magnitude or damage with the flooding that occurred in Ames, and much of the mic'west, during the summer of 1993.

This report presents water-surface-elevation profiles for the floods of June 17, 1990, and July 9, 199:. along Squaw Creek and the South Skunk River in Ames, Iowa. The report provides information on floot stages and discharges, flood-flow frequencies, and bench-mark and reference-point descriptions and elevations for the Squaw Creek and South Skunk River Basins in and around Ames, Iowa. The flood history briefly describes the rainfall conditions for the floods that occurred during 1990 and 1993.

A previous report by Lara and Heinitz (1976), "Flood of June 27, 1975 in City of Ames, Iowa," provides information on flooding that occurred in the Ames area prior to and including the 1975 flood. Water-surface profile data from the 1976 report are included in this report for comparison purposes.

\section{Acknowledgments}

This report was prepared by the U.S. Geological Survey (USGS) in cooperation with the Iowa Highway Research Board and the Project Development Division of the Iowa Department of Transportation. Various Federal, State, and local agencies cooperated in the ccllection of streamflow records used in this report, the acknowledg-ment of which is contained in the annual water-data reports of the USGS (U.S. Geological Survey, 1961-95). 


\section{STUDY AREA}

The South Skunk River originates in Hamilton County in central Iowa (fig. 1). It flows in a general south-east direction to its confluence with the North Skunk River (not shown). The flows from the North and South Skunk Rivers combine to form the Skunk River which continues to follow a general south-east course across Iowa until reaching the Mississippi River.

Squaw Creek enters the South Skunk River as a right-bank tributary in the south-east portion of the City of Ames, Story County, Iowa (fig. 1). The two streams collectively drain $556 \mathrm{mi}^{2}$ at their confluence.

The Squaw Creek and South Skunk River Basins upstream of Ames, Iowa, lie within the Des Moines Lobe land-form region of the state. This region was the most recently glaciated part of the state. This last period of glacial activity occurred only 12,000 to 14,000 years ago (Prior, 1991 p. 36). Because of the recent glacial activity, the surface-drainage network of the Des Moines Lobe tends to be immature and poorly defined, with level terrain, potholes, and marshes commonly occurring. As a result, basins in the region tend to have minimal drainage efficiency, leading to lower peak discharges than those that occur on streams in steeper and more mature basins elsewhere within the state (Lara, 1987, p. 2)

Mean annual precipitation for 1961-90 at the Ames 8 WSW weather station (fig. 1) was 32.94 in. The mean annual precipitation at Jewell, Iowa, centrally located in the contributing drainage basin above Ames (fig. 1), was nearly identical at 32.87 in. for the same period (Owenby and Ezell, 1992).

Although the mean annual precipitation has been nearly uniform throughout the contributing drainage basin upstream of Ames, the mean annual runoff for Squaw Creek and the South Skunk River at Ames show considerable variation. Mean annual runoff for the Squaw Creek drainage basin upstream of Ames was 9.43 in. as determined from records at the streamflowgaging station Squaw Creek at Ames (station number 05470500) for the period 1920-94 (May and others, 1995, p. 113). Mean annual runoff for the South Skunk River drainage basin upstream of Ames was 7.56 in. as determined from records at the streamflow-gaging station South Skunk River near Ames (station number
05470000) for the period 1921-94 (May and others, 1995 , p. 112). This variation in mean annual runoff between Squaw Creek and the South Skunk River drainage basins upstream of Ames is reflected in the flood histories and characteristics of these strec ms at Ames.

\section{HYDROLOGIC DATA}

Gaging-station records are the primary scurce of data for analyzing and understanding the flood hydrology of a river basin. Flood information is obtained from complete-record streamflow-gaging static $n s$, which provide a continuous chronology of strea mflow, and from partial-record, crest-stage streamflow-gaging stations, which provide a chronology of annual peak flows. There are three active USGS continuous-record gaging stations and no crest-stage gaging statior $s$ in the vicinity of Ames, Iowa, as shown in figure 1. T'e specific location, annual-peak stages and discharges, and other information pertaining to each gaging station are presented in Appendix A. Discharge records for these gaging stations are published in the annual water-data reports of the USGS (U.S. Geological Survey, 1961-95).

The computation of discharge records at a gaging station is dependent upon the development of a stagedischarge relation, or rating curve, between water-surface elevations (stages) and the corresponding flow rates (discharges). The high-water part of the stage-discharge relation generally remains stable if the channel downstream from the gaging station remains unchanged. Changes in the stage-discharge relation occur from time to time, either gradually or abruptly, due to changes in the river channel that result f"om scour, deposition, or the growth of vegetation (Rantz and others, 1982, p. 328-360).

\section{FLOODFLOW FREQUENCIES}

The magnitude and frequency of flood discharges, or floodflow frequencies, for a streamflowgaging station are determined from a flood-freauency curve which relates observed annual-peak discharges to annual exceedance probability or recurrence interval. Annual exceedance probability is expressed as the chance that a specified flood magnitude will be 

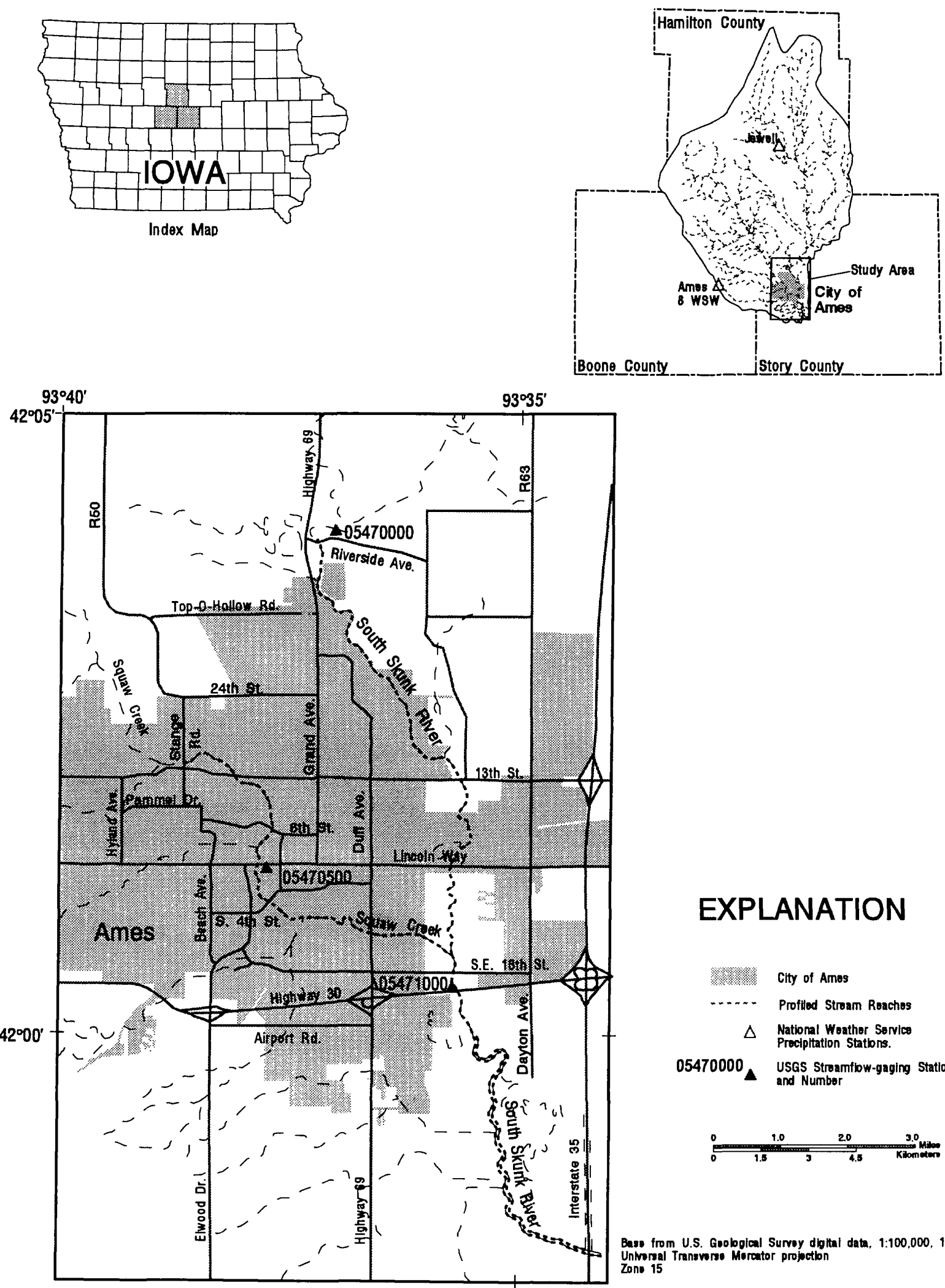

\section{EXPLANATION}

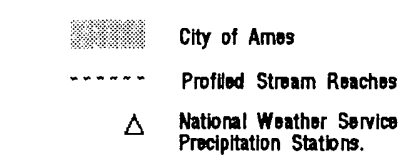

05470000 USGS Stroamfibw-gaging Station

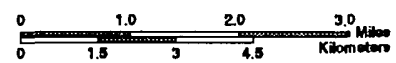

Baso from U.S. Gsobogical Survoy digitai data, 1:100,000, 1992 Universal Tranowera Morator projection Zono 15

Figure 1. Map showing profiled stream reaches, active U.S. Geological Survey streamflow-gaging stations, and selected roads in the study area. 
exceeded in any 1 year. Recurrence interval, which is the reciprocal of the annual exceedance probability, is the statistical average number of years between exceedances of a specified flood magnitude. For example, a flood with a magnitude that is expected to be exceeded on average once during any 100 -year period (recurrence interval) has a 1-percent chance (annual exceedance probability $=0.01$ ) of being exceeded during any 1 year. This flood, commonly termed the 100-year flood, is the theoretical peak discharge against which actual flood peaks generally are compared. Although the recurrence interval represents the longterm average period between floods of a specific magnitude, rare floods could occur at shorter intervals or even within the same year.

A method for determining floodflow frequencies using streamflow-discharge data is outlined in Bulletin 17B of the Interagency Advisory Committee on Water Data (IACWD, 1982, p. 1-28). The IACWD recommends using the Pearson Type-III distribution with log transformation of the data, commonly known as the log-Pearson Type-III distribution, as a base method for determining floodflow frequencies. At least 10 years of gaged annual-peak discharges are required to compute floodflow frequencies. In this report, this method for determining floodflow frequencies is referred to as the "Bulletin 17B" method.

Floodflow frequencies computed for a gaging station, and recurrence intervals determined for selected flood peaks are statistics that can change when recalculated as more data become available. These statistics become more reliable as more data are collected and used in the computations. USGS streamflow-gaging stations are the primary source of the stream-flow data used in the computations.

Other methods for determining floodflow frequencies at stream sites in Iowa, including those not gaged, are described by Lara (1987, p. 2-19) and Eash (1993, p. 9-41). Lara (1987) used the physiographic characteristics of Iowa as a guide in defining the boundaries of five hydrologic regions. Regional equations were developed by using the floodflow frequencies for all gaged stations in a hydrologically, homogeneous area, thereby reducing potential errors associated with nonrepresentative, short-term stations. For this reason, a regional analysis may produce improved estimates of the flood characteristics at gaged sites.
Two alternative methods for estimating floodflow frequencies for stream sites in Iowa were developed by Eash (1993). For the first method, statewide, drainage-basin equations were developed by relating significant drainage-basin characteristics (quantified using a geographic-information-system procedure) to the floodflow frequencies for 164 streamflow-g 7 ging stations in Iowa. For the second method, statewide and regional channel-geometry equations were developed by relating significant channel-geometry characteristics (measured onsite) to the floodflow frequencies for 157 streamflow-gaging stations in Iowa. Lara (1987) and Eash (1993) both used the Bulletin 17B method as the base method for developing their floodestimation equations.

The floodflow frequencies computed usiro the Bulletin 17B method, the regional method of Lara (1987), and the drainage-basin and channel-gec metry characteristic methods of Eash (1993) for the active gaging stations near Ames, Iowa, are listed in table 1. The discharges determined by the Bulletin 17B method use data collected through the 1994 water year, including available historic flood data. It should be noted that different flood-frequency discharges have been computed for these gaging stations by other agencie using the standard log-Pearson Type-III distribution of Bulletin 17B but with different periods of record, dif ${ }^{f}$ erent generalized skew coefficients, and different approaches to the use of historical flood information.

\section{FLOOD HISTORY}

Continuous records of streamflow have been collected in the vicinity of Ames, Iowa, from as early as May, 1919, at the USGS streamflow-gaging station Squaw Creek at Ames, Iowa (station number 05470500). Selected flood-peak discharges, including maximum known flood-peak discharges, and recurrence intervals for the three active streamflow-gaging stations in the Ames area are listed in table 2.

The June 27, 1975, and prior floods in Ames are discussed in detail in the report "Flood of June 27, 1975 in City of Ames, Iowa," (Lara and Heinitz, 1976). A discussion of floods throughout the entire Skunk River Basin can be found in the report, "Floods in the Skunk River Basin, Iowa," (Heinitz and Wiitala, 1978). 
Table 1. Floodflow frequencies for active streamflow-gaging stations along Squaw Creek and the South Skunk River in Ames, lowa, and vicinity

[17B, Bulletin 17B (Interagency Advisory Committee on Water Data, 1982); Lara, floodflow-frequency equations for hydrologic region 4 (Lara, 1987, p. 28); DB, drainage-basin characteristic floodflow-frequency equation (Eash, 1993, p. 17); CG, channel-geometry characteristic floodflow-frequency equation (Region II, bankfull; Eash, 1993, p. 26)]

\begin{tabular}{|c|c|c|c|c|c|c|c|c|}
\hline \multirow{2}{*}{$\begin{array}{c}\text { Station } \\
\text { number } \\
\text { (fig.1) }\end{array}$} & \multirow[b]{2}{*}{ Station name } & \multirow[b]{2}{*}{ Method } & \multicolumn{6}{|c|}{$\begin{array}{l}\text { Discharge, in cubic feet per second, } \\
\text { for indicated recurrence interval, in years }\end{array}$} \\
\hline & & & 2 & 5 & 10 & 25 & 50 & 100 \\
\hline \multirow[t]{4}{*}{05470000} & South Skunk River near Ames & 17B & 3,140 & 4,890 & 5,990 & 7,280 & 8,180 & 9,010 \\
\hline & & Lara & 2,600 & 4,220 & 5,500 & 7,250 & 8,020 & 9,550 \\
\hline & & DB & 3,620 & 6,260 & 8,210 & 10,600 & 12,400 & 14,300 \\
\hline & & CG & 2,330 & 4,280 & 5,710 & 7,530 & 9,080 & 10,700 \\
\hline \multirow[t]{4}{*}{05470500} & Squaw Creek at Ames & $17 \mathrm{~B}$ & 2,680 & 4,720 & 6,390 & 8,870 & 11,000 & 13,400 \\
\hline & & Lara & 1,860 & 3,080 & 4,050 & 5,390 & 6,020 & 7,200 \\
\hline & & DB & 3,150 & 5,520 & 7,300 & 9,530 & 11,300 & 13,000 \\
\hline & & CG & 2,230 & 4,130 & 5,540 & 7,330 & 8,870 & 10,400 \\
\hline \multirow[t]{4}{*}{05471000} & South Skunk River below Squaw & 17B & 6,070 & 8,750 & 10,600 & 13,000 & 14,900 & 16,800 \\
\hline & Creek near Ames & Lara & 4,030 & 6,350 & 8,180 & 10,700 & 11,700 & 13,800 \\
\hline & & DB & 5,270 & 8,880 & 11,500 & 14,700 & 17,100 & 19,200 \\
\hline & & CG & 4,670 & 8,310 & 10,900 & 14,200 & 16,900 & 19,700 \\
\hline
\end{tabular}

\section{Flood of June 17, 1990}

Following a wet spring with excessive precipitation in both March and May, persistent and widespread rainfall occurred throughout the State of Iowa in June of 1990 (Hillaker, 1990). On average, 8.05 in. of rain fell over the state, making it the fourth wettest June in the 118 years of state records available at the time (State Climatology Office, 1990). This rainfall, over antecedent wet soil conditions, resulted in flooding across much of central and east-central Iowa. As a result of the widespread flooding, 44 of Iowa's 99 counties received State disaster declarations, with 33 of these counties receiving Federal disaster designations.

Extensive rainfall on June 17 and the preceding few days was responsible for much of the flooding, including the Ames area. For the five-day period of June 13-17, 4.33 and $5.90 \mathrm{in}$. of rainfall were recorded at the Ames 8 WSW gage and further upstream in the basin at Jewell, respectively (National Oceanic and
Atmospheric Administration, 1990), culminating in damaging flooding in Ames on the morning of June 17. This flooding forced the evacuation of approximately 30 households and closed 16 blocks of Duff Avenue (fig. 1) (Des Moines Register, June 18, 1990).

At the Squaw Creek at Ames streamflow-gagir ; station, the peak discharge recorded on June 17, 1990, was the maximum discharge for the period of record available up to that time. This flood peak of $12,500 \mathrm{ft}^{3} / \mathrm{s}$ had a recurrence interval of approximately 75 years (table 2). The peak stage associated with this flood exceeded the June 27, 1975 peak stage by nearly $2 \mathrm{ft}$ at the Squaw Creek gage.

\section{Flood of July 9, 1993}

From mid-June through early August 1993, severe flooding in a nine-state area of the upper Miss:ssippi River Basin followed an extended period of persistent precipitation that began in January. Flood-peak 


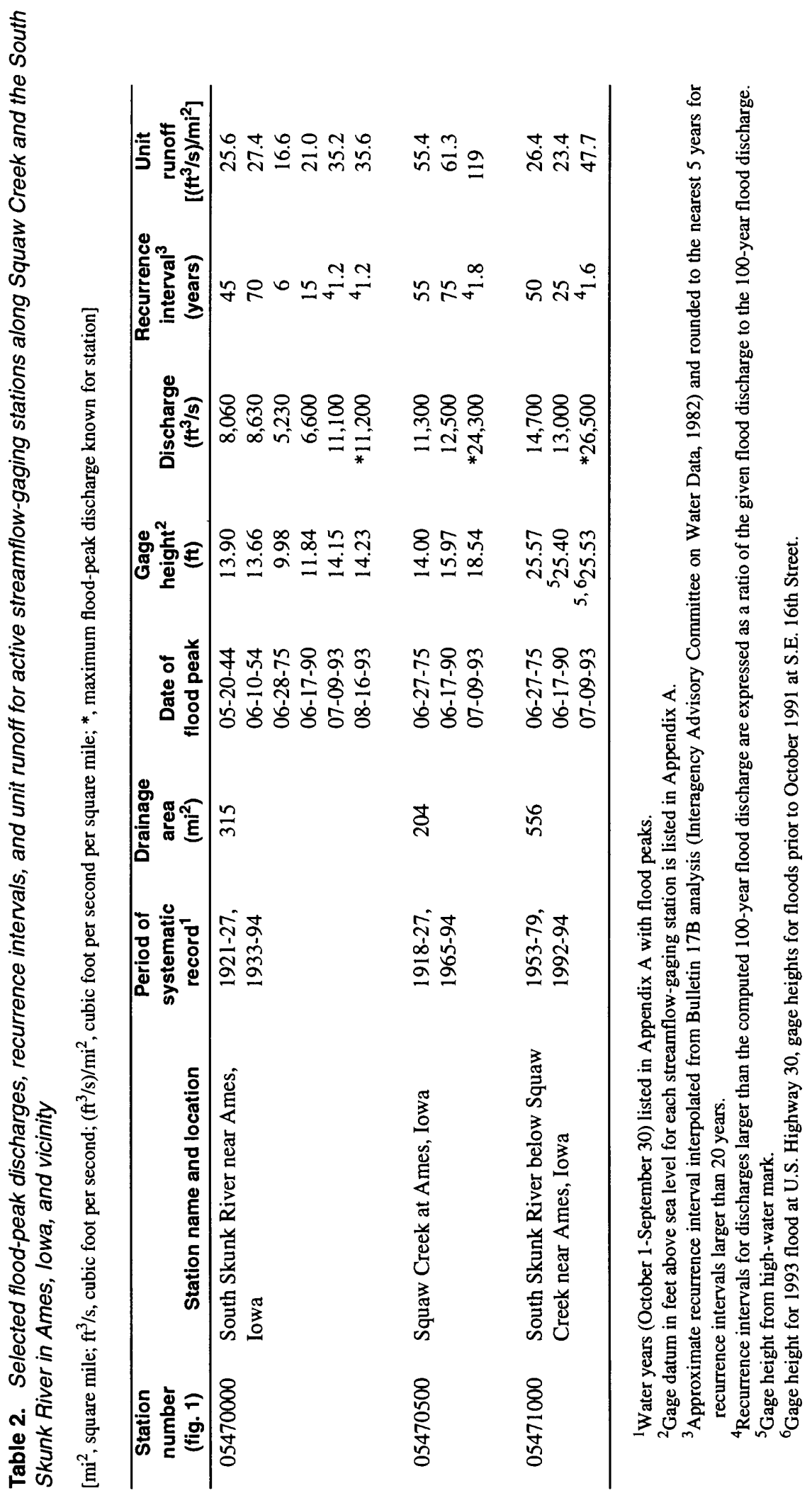


discharges that equalled or exceeded the 10-year recurrence interval were recorded at 154 streamflow-gaging stations in the flooded region during June through August 1993 (Parrett and others, 1993). During the two-day period of July 8-9, 1993, the Ames 8 WSW weather station received 5.36 inches of rain, while further upstream in the basin the rainfall gage at Jewell recorded 4.44 inches of rain (National Oceanic and Atmospheric Administration, 1993). On July 9, 1993, floodwaters from Squaw Creek and the South Skunk River inundated large parts of the Ames area, including Interstate 35, U.S. Highway 30, businesses along Duff Avenue, and parts of the Iowa State University campus (Des Moines Register, 1993). The magnitude of this flood was larger than any previous flood on record that had occurred in the City of Ames, exceeding the June 27-28, 1975, and June 17, 1990, floods both in magnitude and damage in the Ames area. New peak-discharge records were set at each of the three USGS continuous-record gages in the Ames area, although the July 9th discharge at the South Skunk River near Ames gage was slightly exceeded later that same summer by a less-damaging flood on August 16. The peak discharge on July 9, 1993, at the Squaw Creek at Ames gage was $24,300 \mathrm{ft}^{3} / \mathrm{s}, 1.8$ times the computed magnitude of the 100-year flood, and almost 2 times the magnitude of the previous record flood-peak of $12,500 \mathrm{ft}^{3} / \mathrm{s}$ from June 17, 1990. The peak discharge at the South Skunk River below Squaw Creek near Ames gage was $26,500 \mathrm{ft}^{3} / \mathrm{s}, 1.6$ times the computed magnitude of the 100 -year flood, and 1.8 times the magnitude of the previous record flood-peak of $14,700 \mathrm{ft}^{3} / \mathrm{s}$ from June 27 , 1975.

\section{FLOOD PROFILE}

The water-surface-elevation profiles for the June 27, 1975, June 17, 1990, and July 9, 1993 floods on Squaw Creek and the South Skunk River in Ames, Iowa and vicinity are shown in Appendix B (figs. 2 and 3). Flood elevations located both immediately downstream and 1 bridge-length upstream from selected bridges were identified within a few days of passage of the flood peak. A low-water profile measured on July 31 and August 1, 1995, also is shown in figures 2 and 3 to indicate the approximate low-end of the range of stage that can occur within the profiled reaches. The profiles were defined using data obtained by the USGS.
Profiles between the bridges are straight-line interpoletions, which provide only an approximation of the water-surface elevations.

River miles for the South Skunk River are referenced to the mouth of Skunk River at the Mississippi River. River miles for Squaw Creek are referenced to the mouth of Squaw Creek at the South Skunk River. The river miles presented in this report are consistent with the river miles presented in previously publishec' reports (Lara and Heinitz, 1976; Heinitz and Wiitala, 1978). Measurements of river miles using lower- or higher-resolution data or different technologies such as geographic information systems may yield different values than those contained in this report. Bridges are designated by an index number that helps to identify their location. For example, 8323-30SE refers to a location in Township 83 North, Range 23 West, southeast quarter of section 30 .

Differential leveling was performed to reference. all the points along the profiles to a common datum, sea level. A bench mark and a reference point were established at the majority of the bridges in the profiled reach. Bench-mark and reference-point descriptions and elevations are listed in Appendix C.

Bridge-deck and low-bridge-chord elevations are shown in figures 2 and 3 to indicate the relation between the elevation of important components of the bridges and the elevation of the profiled flood and lowwater. For sloping bridges, the profiled bridge-deck and low-bridge-chord elevations represent the lower end of the bridges.

\section{CONSIDERATIONS}

The user of this report is cautioned that the stagedischarge data presented are representative of the physical conditions of the basin at the time of the floods described. Changes in the basin can alter the flood magnitude for a given frequency. Examples of these basin changes include, but are not limited to, extensive urbanization, implementation of agricultural conservation practices, and installation of drainage systems. Changes in the channel conditions immediately downstream from a streamflow-gaging station can substantially affect the stage-discharge relation. Examples of such changes include the construction of dams, bridges, or levees; changes in the flood-plain vegetative cover; straightening of the channel; and natural scour and fill. Temporary changes can be caused by ice 
and debris jams that produce backwater conditions and can cause the water-surface elevations to plot higher than the normal profile.

\section{SUMMARY}

This report provides information on the floods of June 17, 1990, and July 9, 1993, on Squaw Creek and the South Skunk River in Ames, Iowa and vicinity. While the June 17, 1990, flood-peak discharge of $12,500 \mathrm{ft}^{3} / \mathrm{s}$ at the Squaw Creek streamflow-gaging station was the largest recorded discharge up to that time, it was substantially exceeded by the $24,300 \mathrm{ft}^{3} / \mathrm{s}$ peak discharge recorded at the gage on July 9, 1993. The July 9, 1993, flood set new discharge records at all three streamflow-gaging stations in the Ames area on Squaw Creek and the South Skunk River, with peak discharges at the gages ranging from 1.2 to 1.8 times the computed 100-year flood discharges. The July 9, 1993, peak-discharge at the South Skunk River near Ames streamflow-gaging station was subsequently exceeded later that same year on August 16.

\section{REFERENCES}

Des Moines Register, 1990, June 18 newspaper article.

Des Moines Register, 1993, July 13 newspaper article.

Eash, D.A., 1993, Estimating design-flood discharges for streams in Iowa using drainage-basin and channelgeometry characteristics: U.S. Geological Survey Water-Resources Investigation Report 93-4062, 96 p.

Heinitz, A.J., and Wiitala, S.W., 1978, Floods in the Skunk River Basin, Iowa: U.S. Geological Survey Open-File Report 79-272, 80 p.

Hillaker, H., 1990, Preliminary monthly summary-June 1990: State Climatology Office, Iowa Department of Agriculture and Land Stewardship, 4 p.

Interagency Advisory Committee on Water Data (IACWD), 1982, Guidelines for determining flood flow frequency: Hydrology Subcommittee Bulletin 17B, U.S. Geological Survey, Office of Water Data Coordination, 28 p. and appendices.

Lara, O.G., 1987, Method for estimating the magnitude and frequency of floods at ungaged sites on unregulated rural streams in Iowa: U.S. Geological Survey WaterResources Investigation Report 87-4132, 34 p.
Lara, O.G., and Heinitz, A.J., 1976, Flood of June 27, 1975 in City of Ames, Iowa: U.S. Geological Survey OpenFile Report, 56 p.

May, J.E., and others, 1995, Water resources data, Iowa, water year 1994: U.S. Geological Survey Water-Data Report IA-94-1, 370 p.

National Oceanic and Atmospheric Administration, 1990, Climatologic data, Iowa: Asheville, N.C., monthly summaries, v. 101, no. 6, 34 p.

-1993, Climatologic data, Iowa: Asheville, N.C., monthly summaries, v. 104, no. 7, 38 p.

Novak, C.E., 1985, WRD data reports preparation guide: Reston, Virginia, U.S. Geological Survey, 199 p.

Owenby, J.R., and Ezell, D.S., 1992, Monthly static n normals of temperature, precipitation, and heating and cooling degree days 1961-1990, Iowa: Climatcoraphy of the United States No. 81, National Oceanic and Atmospheric Administration, National Climatir. Data Center, 32 p.

Parrett, Charles, Melcher, N.B., and James, R.W., 1993, Flood discharges in the upper Mississippi River Basin, 1993: U.S. Geological Survey Circular 1120- $A$. 14 p.

Prior, J.C., 1991, Landforms of Iowa: Iowa City, Io'va, Department of Natural Resources, University of Iowa Press, $153 \mathrm{p}$.

Rantz, S.E., and others, 1982, Measurement and computation of streamflow--Volume 2. Computation of discharge: U.S. Geological Survey Water-Supply Paper 2175 , p. 285-631.

State Climatology Office, 1990, Iowa climate revie'N-June 1990: Iowa Department of Agriculture and Land Stewardship, vol. 4, no. 6, 25 p.

U.S. Geological Survey, 1961-95, Water resources data, Iowa, water years 1961-94 (published annually): U.S. Geological Survey Water-Data Reports. 


\section{APPENDIX A}

\section{PEAK STAGES AND DISCHARGES FOR ACTIVE STREAMFLOW- GAGING STATIONS ALONG SQUAW CREEK AND THE SOUTH SKUNK RIVER IN AMES, IOWA, AND VICINITY, 1918-1994}

The peak-stage and discharge data for this report were compiled through September 30, 1994, for the active continuous-record streamflow-gaging stations located in the Squaw Creek and South Skunk River Basins near Ames, Iowa. The floods, designated by calendar date, are in chronological order and grouped by water year (October 1 September 30). In general, independent flood peaks above a pre-selected base (partial-duration series) are listed for the continuous-record gaging stations. The magnitude of the selected base discharge, given in the "Remarks" section of the headnote, was determined so that it would be equaled or exceeded on the average of about three times per year. Two flood peaks are considered independent if a plot of the recorded stages indicates a well-defined trough between the peaks and if the instantaneous discharge of the trough is 25 percent or more below that of the lower peak (Novak, 1985, p. 93).

The gaging-station records are arranged in downstream order as explained in the annual streamflow reports of the U.S. Geological Survey (see "References"). The gaging stations are identified by a permanent number that is also used in figure 1 and in tables 1 and 2 of this report. The datum of each gage is sea level. For those gaging stations which are used by the National Weather Service
(NWS) as forecast points, the flood stage, as determined $\mathrm{ty}$ the NWS, is listed. For those gaging stations which are used by the NWS as data points, the bankfull stage, as determined by the NWS, is listed. The flood stage is the stage at which overflow of the natural banks of the stream begins to cause. damage in the reach in which the elevation is measured, while the bankfull stage is the maximum stage which can occur without overflowing the natural banks of the stream. records:

The following notations are used in the gaging-station

1. A dashed line in the "water year" column denotes a break or gap in the record of peaks.

2. A dashed line beginning at the "date" column and continuing through the "discharge" column indicates a change in site and datum.

3. A dashed line in the "date" and "discharge" columns indicates a change in site without a change in datum.

4. A dashed line in the "gage height" column denotes a change in datum only.

The remainder of the information given is self-explanatory. 


\section{South Skunk River near Ames, Iowa}

Location.--Lat $42^{\circ} 04^{\prime} 06^{\prime \prime}$, long $93^{\circ} 37^{\prime} 09^{\prime \prime}$, in NW1/4 SW1/4 sec.23, T.84 N., R.24 W., Story County, Hydrolc gic Unit 07080105 , on left bank 2.5 mi north of Ames, 3.5 mi downstream from Keigley Branch, 5.2 mi upstream from Squaw Creek, and at mile 228.1 upstream from mouth of Skunk River.

Drainage area.--315 $\mathrm{mi}^{2}$.

Gage.--Water-stage encoder. Concrete control since July 21, 1934. Datum of gage is $893.61 \mathrm{ft}$ above sea level (Iowa Highway Commission bench mark). Prior to Aug. 25, 1921, nonrecording gage at same site and datum.

Stage-discharge relation.--Defined by current-meter measurements.

Flood stage. $-9 \mathrm{ft}$.

Remarks.--Base for partial-duration series, $1,500 \mathrm{ft}^{3} / \mathrm{s}$.

\section{Peak stages and discharges}

[ft, feet above gage datum; $\mathrm{ft}^{3} / \mathrm{s}$, cubic feet per second; (A), discharge not determined; (B), gage height not determined]

\begin{tabular}{|c|c|c|c|}
\hline Water year & Date & $\begin{array}{c}\text { Gage height } \\
\text { (ft) }\end{array}$ & $\begin{array}{c}\text { Discharge } \\
\left(\mathrm{ft}^{3} / \mathrm{s}\right)\end{array}$ \\
\hline 1921 & Sept. 17,1921 & 9.20 & 3,540 \\
\hline 1922 & Feb. 23,1922 & 9.00 & 3,370 \\
\hline 1923 & $\begin{array}{l}\text { Mar. } 28,1923 \\
\text { Sept. } 28,1923\end{array}$ & $\begin{array}{l}6.22 \\
6.00\end{array}$ & $\begin{array}{l}1,670 \\
1,530\end{array}$ \\
\hline 1924 & $\begin{array}{lr}\text { Mar. } & 30,1924 \\
\text { June } & 28,1924 \\
\text { Aug. } & 9,1924\end{array}$ & $\begin{array}{l}6.30 \\
8.21 \\
6.00\end{array}$ & $\begin{array}{l}1,680 \\
3,010 \\
1,500\end{array}$ \\
\hline 1925 & Aug. 7,1925 & 5.00 & 905 \\
\hline 1926 & $\begin{array}{lr}\text { Sept. } & 8,1926 \\
\text { Sept. } 19,1926\end{array}$ & $\begin{array}{l}6.50 \\
8.26\end{array}$ & $\begin{array}{l}1,900 \\
3,120\end{array}$ \\
\hline 1927 & Feb. $\quad 5,1927$ & 7.40 & 2,460 \\
\hline 1930 & Nov. 24, 1929 & 11.20 & 5,230 \\
\hline ----- & & & \\
\hline 1933 & Apr. $\quad 1,1933$ & 6.47 & 1,990 \\
\hline 1934 & Jan. 22,1934 & ${ }^{1} 5.39$ & ${ }^{2} 600$ \\
\hline 1935 & $\begin{array}{lr}\text { Feb. } & 15,1935 \\
\text { Mar. } & 5,1935 \\
\text { June } & 19,1935 \\
\text { June } & 25,1935 \\
\text { July } & 24,1935\end{array}$ & $\begin{array}{l}17.80 \\
9.00 \\
6.50 \\
8.40 \\
7.00\end{array}$ & $\begin{array}{r}2,490 \\
3,490 \\
1,900 \\
2,960 \\
2,190\end{array}$ \\
\hline 1936 & Mar. 10, 1936 & 7.70 & 2,580 \\
\hline 1937 & Mar. $\quad 6,1937$ & ${ }^{1} 8.40$ & 23,000 \\
\hline
\end{tabular}




\section{South Skunk River near Ames, Iowa}

Peak stages and discharges-Continued

\begin{tabular}{|c|c|c|c|}
\hline Water year & Date & $\begin{array}{l}\text { Gage height } \\
\text { (ft) }\end{array}$ & $\begin{array}{c}\text { Discharge } \\
\left(\mathrm{ft}^{3} / \mathrm{s}\right)\end{array}$ \\
\hline 1938 & $\begin{array}{lr}\text { May } & 4,1938 \\
\text { May } & 17,1938 \\
\text { June } & 29,1938\end{array}$ & $\begin{array}{l}8.30 \\
6.50 \\
5.80\end{array}$ & $\begin{array}{l}2,890 \\
1,880 \\
1,540\end{array}$ \\
\hline 1939 & Mar. 14,1939 & ${ }^{1} 10.50$ & ${ }^{2} 3,230$ \\
\hline 1940 & Aug. 13,1940 & 7.30 & 2,320 \\
\hline 1941 & Sept. 8,1941 & 8.60 & 3,050 \\
\hline 1942 & $\begin{array}{l}\text { Nov. } 1,1941 \\
\text { Sept. } 14,1942\end{array}$ & $\begin{array}{l}5.90 \\
8.10\end{array}$ & $\begin{array}{l}1,630 \\
2,530\end{array}$ \\
\hline 1943 & $\begin{array}{l}\text { June } 16,1943 \\
\text { July } 31,1943\end{array}$ & $\begin{array}{r}6.50 \\
10.30\end{array}$ & $\begin{array}{l}1,910 \\
4,500\end{array}$ \\
\hline 1944 & $\begin{array}{l}\text { May } 20,1944 \\
\text { June } 12,1944\end{array}$ & $\begin{array}{r}13.90 \\
8.00\end{array}$ & $\begin{array}{l}8,060 \\
2,840\end{array}$ \\
\hline 1945 & $\begin{array}{lr}\text { Mar. } & 16,1945 \\
\text { May } & 22,1945 \\
\text { June } & 2,1945\end{array}$ & $\begin{array}{l}6.30 \\
7.70 \\
9.70\end{array}$ & $\begin{array}{l}1,800 \\
2,620 \\
4,010\end{array}$ \\
\hline 1946 & $\begin{array}{lr}\text { Feb. } & 5,1946 \\
\text { Mar. } & 6,1946 \\
\text { Mar. } & 13,1946\end{array}$ & $\begin{array}{l}7.10 \\
5.90 \\
5.90\end{array}$ & $\begin{array}{l}2,270 \\
1,600 \\
1,610\end{array}$ \\
\hline 1947 & $\begin{array}{cr}\text { June } & 1,1947 \\
\text { June } & 4,1947 \\
\text { June } & 13,1947 \\
\text { June } & 23,1947 \\
\text { June } & 30,1947\end{array}$ & $\begin{array}{r}8.63 \\
8.18 \\
11.95 \\
10.80 \\
6.40\end{array}$ & $\begin{array}{l}3,740 \\
3,400 \\
6,550 \\
5,400 \\
2,200\end{array}$ \\
\hline 1948 & $\begin{array}{ll}\text { Feb. } & 28,1948 \\
\text { Mar. } & 19,1948 \\
\text { Mar. } 27,1948\end{array}$ & $\begin{array}{l}5.80 \\
7.35 \\
7.30\end{array}$ & $\begin{array}{l}1,630 \\
2,620 \\
2,600\end{array}$ \\
\hline 1949 & Mar. $\quad 4,1949$ & ${ }^{1} 10.52$ & 23,000 \\
\hline 1950 & $\begin{array}{lr}\text { Mar. } & 7,1950 \\
\text { May } & 5,1950 \\
\text { May } & 9,1950 \\
\text { June } & 9,1950 \\
\text { June } & 18,1950\end{array}$ & $\begin{array}{l}8.86 \\
6.00 \\
7.00 \\
5.80 \\
6.60\end{array}$ & $\begin{array}{l}3,820 \\
1,810 \\
2,410 \\
1,690 \\
2,170\end{array}$ \\
\hline 1951 & $\begin{array}{lr}\text { Feb. } & 26,1951 \\
\text { Mar. } & 29,1951 \\
\text { May } & 2,1951 \\
\text { June } & 2,1951 \\
\text { June } & 20,1951 \\
\text { July } & 4,1951\end{array}$ & $\begin{array}{r}5.75 \\
10.90 \\
6.75 \\
10.35 \\
6.25 \\
7.07\end{array}$ & $\begin{array}{l}1,690 \\
5,320 \\
2,290 \\
4,920 \\
1,930 \\
2,470\end{array}$ \\
\hline 1952 & July $\quad 9,1952$ & 5.73 & 1,630 \\
\hline 1953 & May 1,1953 & 4.71 & 980 \\
\hline
\end{tabular}


05470000 South Skunk River near Ames, Iowa

Peak stages and discharges-Continued

\begin{tabular}{|c|c|c|c|}
\hline Water year & Date & $\begin{array}{c}\text { Gage height } \\
\text { (ft) }\end{array}$ & $\begin{array}{c}\text { Discharge } \\
\left(\mathrm{ft}^{3} / \mathrm{s}\right)\end{array}$ \\
\hline 1954 & $\begin{array}{cr}\text { June } & 1,1954 \\
\text { June } & 10,1954 \\
\text { June } & 16,1954 \\
\text { June } & 22,1954 \\
\text { Aug. } & 27,1954\end{array}$ & $\begin{array}{r}7.84 \\
13.66 \\
6.37 \\
5.88 \\
8.27\end{array}$ & $\begin{array}{l}3,180 \\
8,630 \\
2,110 \\
1,770 \\
3,520\end{array}$ \\
\hline 1955 & Oct. 15,1954 & 5.22 & 1,340 \\
\hline 1956 & Sept. 4,1956 & 3.49 & 376 \\
\hline 1957 & $\begin{array}{lr}\text { June } & 16,1957 \\
\text { July } & 4,1957\end{array}$ & $\begin{array}{l}8.28 \\
6.52\end{array}$ & $\begin{array}{l}3,540 \\
2,200\end{array}$ \\
\hline 1958 & $\begin{array}{lr}\text { July } & 2,1958 \\
\text { July } & 4,1958 \\
\text { July } & 11,1958\end{array}$ & $\begin{array}{l}6.55 \\
7.85 \\
5.78\end{array}$ & $\begin{array}{l}2,270 \\
3,150 \\
1,720\end{array}$ \\
\hline 1959 & $\begin{array}{l}\text { Mar. } 20,1959 \\
\text { May } 31,1959\end{array}$ & $\begin{array}{l}5.60 \\
5.83\end{array}$ & $\begin{array}{l}1,590 \\
1,720\end{array}$ \\
\hline 1960 & $\begin{array}{l}\text { Mar. } 30,1960 \\
\text { May } 7,1960\end{array}$ & $\begin{array}{r}10.33 \\
5.59\end{array}$ & $\begin{array}{l}6,210 \\
1,590\end{array}$ \\
\hline 1961 & $\begin{array}{lr}\text { Feb. } & 23,1961 \\
\text { Mar. } & 15,1961 \\
\text { Aug. } & 2,1961\end{array}$ & $\begin{array}{l}5.71 \\
5.51 \\
5.51\end{array}$ & $\begin{array}{l}1,990 \\
1,770 \\
1,770\end{array}$ \\
\hline 1962 & $\begin{array}{lr}\text { Mar. } & 26,1962 \\
\text { May } & 7,1962 \\
\text { May } & 30,1962 \\
\text { July } & 14,1962 \\
\text { July } & 22,1962\end{array}$ & $\begin{array}{l}6.91 \\
7.53 \\
5.72 \\
9.02 \\
5.72\end{array}$ & $\begin{array}{l}3,010 \\
3,510 \\
1,970 \\
4,300 \\
1,970\end{array}$ \\
\hline 1963 & Apr. 30,1963 & 5.65 & 1,820 \\
\hline 1964 & $\begin{array}{rr}\text { May } & 8,1964 \\
\text { June } & 22,1964\end{array}$ & $\begin{array}{l}5.31 \\
5.91\end{array}$ & $\begin{array}{l}1,570 \\
2,170\end{array}$ \\
\hline 1965 & $\begin{array}{lr}\text { Mar. } & 1,1965 \\
\text { Apr. } & 2,1965 \\
\text { Apr. } & 6,1965 \\
\text { May } & 27,1965 \\
\text { June } & 6,1965 \\
\text { Sept. } & 20,1965 \\
\text { Sept. } & 28,1965\end{array}$ & $\begin{array}{l}17.49 \\
17.25 \\
9.43 \\
6.55 \\
5.75 \\
6.92 \\
5.34\end{array}$ & $\begin{array}{r}23,500 \\
23,300 \\
5,260 \\
2,730 \\
2,020 \\
3,030 \\
1,610\end{array}$ \\
\hline 1966 & $\begin{array}{lr}\text { Feb. } & 9,1966 \\
\text { May } & 23,1966 \\
\text { June } & 12,1966\end{array}$ & $\begin{array}{r}{ }^{1} 6.92 \\
5.87 \\
6.26\end{array}$ & $\begin{array}{r}22,900 \\
1,960 \\
2,510\end{array}$ \\
\hline 1967 & $\begin{array}{lr}\text { June } & 8,1967 \\
\text { June } & 13,1967 \\
\text { June } & 18,1967\end{array}$ & $\begin{array}{l}6.63 \\
5.87 \\
6.06\end{array}$ & $\begin{array}{l}2,790 \\
2,140 \\
2,320\end{array}$ \\
\hline 1968 & June 25,1968 & 8.74 & 4,890 \\
\hline
\end{tabular}




\section{South Skunk River near Ames, Iowa}

Peak stages and discharges-Continued

\begin{tabular}{|c|c|c|c|}
\hline Water year & Date & $\begin{array}{l}\text { Gage height } \\
\text { (ft) }\end{array}$ & $\begin{array}{c}\text { Discharge } \\
\left(\mathrm{ft}^{3} / \mathrm{s}\right)\end{array}$ \\
\hline \multirow[t]{8}{*}{1969} & Mar. 20, 1969 & 7.97 & 3,910 \\
\hline & Mar. 25, 1969 & 6.27 & 2,510 \\
\hline & June 7,1969 & 6.19 & 2,440 \\
\hline & June 13,1969 & 5.28 & 1,550 \\
\hline & June 30,1969 & 6.88 & 2,910 \\
\hline & July 10,1969 & 8.49 & 4,380 \\
\hline & July 18,1969 & 6.13 & 2,390 \\
\hline & July 28,1969 & 7.32 & 3,360 \\
\hline 1970 & May 13,1970 & 5.10 & 1,330 \\
\hline \multirow[t]{3}{*}{1971} & Feb. 19,1971 & ${ }^{19.10}$ & (A) \\
\hline & Feb. 20,1971 & 7.67 & 3,660 \\
\hline & Mar. 13, 1971 & 6.03 & 2,300 \\
\hline \multirow[t]{4}{*}{1972} & Mar. 7,1972 & $1_{8.93}$ & (A) \\
\hline & June 6,1972 & 5.34 & 1,610 \\
\hline & Aug. 3,1972 & 5.40 & 1,670 \\
\hline & Aug. 7,1972 & 6.92 & 3,030 \\
\hline \multirow[t]{13}{*}{1973} & Oct. 24,1972 & 5.66 & 1,930 \\
\hline & Nov. 2,1972 & 5.33 & 1,600 \\
\hline & Nov. 8,1972 & 5.67 & 1,940 \\
\hline & Dec. 30,1972 & 17.13 & ${ }^{2} 2,790$ \\
\hline & Jan. 18,1973 & ${ }^{1} 6.19$ & ${ }^{2} 2,210$ \\
\hline & Feb. $\quad 2,1973$ & 17.94 & 22,470 \\
\hline & Mar. 1,1973 & 5.29 & 1,560 \\
\hline & Mar. 11, 1973 & 5.77 & 2,040 \\
\hline & Mar. 14,1973 & 5.53 & 1,800 \\
\hline & Apr. 16,1973 & 7.30 & 3,340 \\
\hline & May 8,1973 & 6.12 & 2,380 \\
\hline & May 28,1973 & 5.38 & 1,650 \\
\hline & Sept. 27,1973 & 5.83 & 2,100 \\
\hline \multirow[t]{10}{*}{1974} & Oct. 12,1973 & 6.70 & 2,850 \\
\hline & Apr. 22,1974 & 5.10 & 1,730 \\
\hline & May 14,1974 & 5.17 & 1,800 \\
\hline & May 16,1974 & 5.37 & 2,000 \\
\hline & May 19,1974 & 5.50 & 2,130 \\
\hline & May 22,1974 & 5.37 & 2,000 \\
\hline & June 9,1974 & 6.35 & 2,860 \\
\hline & June 19,1974 & 8.90 & 5,100 \\
\hline & June 20,1974 & 6.69 & 3,130 \\
\hline & June 23,1974 & 9.61 & 5,780 \\
\hline \multirow[t]{5}{*}{1975} & Mar. 20, 1975 & 5.94 & 2,170 \\
\hline & June 19,1975 & 5.09 & 1,570 \\
\hline & June 22,1975 & 6.12 & 2,290 \\
\hline & June 25,1975 & 6.19 & 2,340 \\
\hline & June 28,1975 & 9.98 & 5,230 \\
\hline 1976 & June 14,1976 & 7.54 & 3,580 \\
\hline
\end{tabular}




\section{South Skunk River near Ames, Iowa}

Peak stages and discharges-Continued

\begin{tabular}{|c|c|c|c|}
\hline Water year & Date & $\begin{array}{c}\text { Gage height } \\
\text { (ft) }\end{array}$ & $\begin{array}{c}\text { Discharge } \\
\left(\mathrm{ft}^{3} / \mathrm{s}\right)\end{array}$ \\
\hline 1977 & $\begin{array}{lr}\text { Aug. } 9,1977 \\
\text { Aug. } 10,1977 \\
\text { Aug. } 16,1977\end{array}$ & $\begin{array}{l}5.92 \\
6.03 \\
9.46\end{array}$ & $\begin{array}{l}2,080 \\
2,140 \\
5,300\end{array}$ \\
\hline 1978 & $\begin{array}{ll}\text { Apr. } & 18,1978 \\
\text { Sept. } 14,1978 \\
\text { Sept. } 21,1978\end{array}$ & $\begin{array}{l}5.83 \\
5.93 \\
5.34\end{array}$ & $\begin{array}{l}2,100 \\
2,240 \\
1,650\end{array}$ \\
\hline 1979 & $\begin{array}{cc}\text { Mar. } & 19,1979 \\
\text { Mar. } & 23,1979 \\
\text { Mar. } & 30,1979 \\
\text { June } & 13,1979 \\
\text { July } & 11,1979 \\
\text { July } & 30,1979 \\
\text { Aug. } & 21,1979\end{array}$ & $\begin{array}{l}9.13 \\
6.82 \\
7.48 \\
5.62 \\
6.16 \\
5.39 \\
5.53\end{array}$ & $\begin{array}{l}4,980 \\
2,950 \\
3,490 \\
1,880 \\
2,410 \\
1,660 \\
1,800\end{array}$ \\
\hline 1980 & $\begin{array}{l}\text { June } 14,1980 \\
\text { June } 19,1980\end{array}$ & $\begin{array}{l}6.54 \\
5.29\end{array}$ & $\begin{array}{l}2,720 \\
1,560\end{array}$ \\
\hline 1981 & June 25,1981 & 5.61 & 1,880 \\
\hline 1982 & $\begin{array}{ll}\text { Feb. } & 22,1982 \\
\text { Mar. } & 16,1982 \\
\text { Mar. } & 20,1982 \\
\text { June } & 15,1982 \\
\text { July } & 19,1982\end{array}$ & $\begin{array}{l}7.05 \\
5.35 \\
6.39 \\
5.46 \\
7.53\end{array}$ & $\begin{array}{l}3,140 \\
1,630 \\
2,600 \\
1,730 \\
3,490\end{array}$ \\
\hline 1983 & $\begin{array}{lr}\text { Nov. } & 12,1982 \\
\text { Dec. } & 6,1982 \\
\text { Dec. } & 28,1982 \\
\text { Feb. } & 20,1983 \\
\text { Mar. } & 7,1983 \\
\text { Apr. } & 2,1983 \\
\text { Apr. } & 15,1983 \\
\text { May } & 20,1983 \\
\text { July } & 3,1983\end{array}$ & $\begin{array}{l}\text { (B) } \\
\text { (B) } \\
5.62 \\
5.99 \\
5.59 \\
5.75 \\
6.24 \\
6.59 \\
9.43\end{array}$ & $\begin{array}{r}{ }^{3} 1,500 \\
{ }^{3} 1,500 \\
1,790 \\
2,160 \\
1,760 \\
1,970 \\
2,470 \\
2,680 \\
5,150\end{array}$ \\
\hline 1984 & $\begin{array}{lr}\text { Feb. } & 17,1984 \\
\text { May } & 1,1984 \\
\text { June } & 13,1984 \\
\text { June } & 17,1984 \\
\text { June } & 22,1984\end{array}$ & $\begin{array}{l}\text { (B) } \\
5.52 \\
9.19 \\
7.71 \\
5.42\end{array}$ & $\begin{array}{l}2,600 \\
1,790 \\
5,020 \\
3,680 \\
1,680\end{array}$ \\
\hline 1985 & Mar. 4,1985 & 5.75 & 1,980 \\
\hline 1986 & $\begin{array}{ll}\text { Mar. } 14,1986 \\
\text { Mar. } 19,1986 \\
\text { June } 30,1986 \\
\text { Sept. } 20,1986\end{array}$ & $\begin{array}{l}5.48 \\
5.95 \\
8.11 \\
5.58\end{array}$ & $\begin{array}{l}1,740 \\
2,140 \\
4,040 \\
1,840\end{array}$ \\
\hline 1987 & $\begin{array}{rr}\text { Oct. } & 5,1986 \\
\text { Oct. } & 13,1986 \\
\text { July } & 12,1987 \\
\text { Aug. } & 26,1987\end{array}$ & $\begin{array}{l}5.35 \\
6.82 \\
6.84 \\
6.01\end{array}$ & $\begin{array}{l}1,610 \\
2,940 \\
3,040 \\
2,290\end{array}$ \\
\hline 1988 & Nov. 29,1987 & 3.98 & 565 \\
\hline
\end{tabular}




\subsection{South Skunk River near Ames, Iowa}

Peak stages and discharges-Continued

\begin{tabular}{|c|c|c|c|}
\hline Water year & Date & $\begin{array}{c}\text { Gage height } \\
\text { (ft) }\end{array}$ & $\begin{array}{c}\text { Discharge } \\
\left(\mathrm{ft}^{3} / \mathrm{s}\right)\end{array}$ \\
\hline 1989 & Mar. 10,1989 & 14.98 & ${ }^{4} 370$ \\
\hline 1990 & $\begin{array}{ll}\text { May } & 20,1990 \\
\text { May } & 25,1990 \\
\text { June } & 17,1990 \\
\text { June } & 20,1990 \\
\text { June } & 23,1990 \\
\text { July } & 27,1990 \\
\text { July } & 29,1990\end{array}$ & $\begin{array}{r}7.37 \\
5.97 \\
11.84 \\
9.36 \\
6.97 \\
6.45 \\
7.55\end{array}$ & $\begin{array}{l}3,250 \\
2,120 \\
6,600 \\
4,630 \\
2,890 \\
2,600 \\
3,540\end{array}$ \\
\hline 1991 & $\begin{array}{lr}\text { Mar. } & 2,1991 \\
\text { Mar. } & 18,1991 \\
\text { Mar. } & 23,1991 \\
\text { Mar. } & 28,1991 \\
\text { Apr. } & 8,1991 \\
\text { Apr. } & 13,1991 \\
\text { Apr. } & 14,1991 \\
\text { Apr. } & 19,1991 \\
\text { Apr. } & 27,1991 \\
\text { May } & 16,1991 \\
\text { May } & 19,1991 \\
\text { June } & 4,1991\end{array}$ & $\begin{array}{l}5.08 \\
5.56 \\
5.33 \\
5.06 \\
5.24 \\
7.03 \\
7.15 \\
5.50 \\
5.39 \\
7.86 \\
7.30 \\
8.73\end{array}$ & $\begin{array}{l}1,540 \\
1,970 \\
1,780 \\
1,500 \\
1,670 \\
3,260 \\
3,360 \\
1,910 \\
1,820 \\
4,000 \\
3,510 \\
4,700\end{array}$ \\
\hline 1992 & $\begin{array}{l}\text { Mar. } 7,1992 \\
\text { July } 16,1992\end{array}$ & $\begin{array}{l}5.70 \\
6.00\end{array}$ & $\begin{array}{l}2,070 \\
2,350\end{array}$ \\
\hline 1993 & $\begin{array}{lr}\text { Mar. } & 9,1993 \\
\text { Mar. } & 27,1993 \\
\text { Mar. } & 31,1993 \\
\text { May } & 11,1993 \\
\text { June } & 9,1993 \\
\text { June } & 19,1993 \\
\text { July } & 1,1993 \\
\text { July } & 9,1993 \\
\text { July } & 14,1993 \\
\text { July } & 18,1993 \\
\text { Aug. } & 11,1993 \\
\text { Aug. } & 16,1993 \\
\text { Aug. } & 30,1993\end{array}$ & $\begin{array}{r}5.63 \\
5.34 \\
7.14 \\
5.34 \\
5.77 \\
10.22 \\
7.10 \\
14.15 \\
10.25 \\
11.66 \\
5.80 \\
14.23 \\
6.86\end{array}$ & $\begin{array}{r}1,770 \\
1,520 \\
3,220 \\
1,520 \\
1,900 \\
6,360 \\
3,180 \\
11,100 \\
6,390 \\
8,000 \\
1,930 \\
11,200 \\
2,920\end{array}$ \\
\hline 1994 & $\begin{array}{lr}\text { Mar. } & 5,1994 \\
\text { June } & 7,1994 \\
\text { June } & 23,1994\end{array}$ & $\begin{array}{l}6.20 \\
6.20 \\
5.77\end{array}$ & $\begin{array}{l}2,330 \\
2,340 \\
1,940\end{array}$ \\
\hline
\end{tabular}

\footnotetext{
${ }^{1}$ Affected by ice.

${ }^{2}$ Approximate.

${ }^{3}$ Discharge greater than indicated value.

${ }^{4}$ Discharge due to snowmelt or ice-jam breakup
} 


\section{Squaw Creek at Ames, Iowa}

Location.--Lat $42^{\circ} 01^{\prime} 21^{\prime \prime}$, long 93³7'45”, in NE1/4 NW1/4 sec.10, T.83 N., R.24 W., Story County, Hydroloric Unit 07080105, on left bank $65 \mathrm{ft}$ downstream from Lincoln Way Bridge in Ames, 0.2 mi downstream from College Creek, and $2.4 \mathrm{mi}$ upstream from mouth.

Drainage area.--204 $\mathrm{mi}^{2}$.

Gage.--Water-stage recorder and concrete control. Datum of gage is $881.00 \mathrm{ft}$ above sea level (levels by Iowa State University). Prior to Mar. 11, 1925, nonrecording gage at site $0.6 \mathrm{mi}$ upstream at different datum. Mar. 11, 1925, to Apr. 30, 1927, nonrecording gage at site $65 \mathrm{ft}$ upstream at datum about $4 \mathrm{ft}$ higher.

Stage-discharge relation.--Defined by current-meter measurements.

Flood stage.--7 ft.

Remarks.--Base for partial-duration series, $1,600 \mathrm{ft}^{3} / \mathrm{s}$.

Peak stages and discharges

[ft, feet above gage datum; $\mathrm{ft}^{3} / \mathrm{s}$, cubic feet per second; (B), gage height not determined]

\begin{tabular}{|c|c|c|c|}
\hline Water year & Date & $\begin{array}{c}\text { Gage height } \\
\text { (ft) }\end{array}$ & $\begin{array}{c}\text { Discharge } \\
\left(\mathrm{ft}^{3} / \mathrm{s}\right)\end{array}$ \\
\hline 1918 & June 4,1918 & 14.50 & ${ }^{1} 6,900$ \\
\hline 1919 & Sept. 30,1919 & 7.96 & ${ }^{2} 1,900$ \\
\hline 1920 & Oct. $\quad 4,1919$ & 8.60 & 2,260 \\
\hline 1921 & Sept. 17,1921 & 7.40 & 1,900 \\
\hline 1922 & July 17,1922 & 10.70 & 4,130 \\
\hline 1923 & Sept. 28, 1923 & 6.10 & 1,340 \\
\hline 1924 & July 28,1924 & 8.80 & 3,170 \\
\hline 1925 & Aug. 7,1925 & 4.90 & 791 \\
\hline 1926 & Sept. 19,1926 & 10.20 & 3,610 \\
\hline 1927 & Oct. $\quad 4,1926$ & 5.80 & 1,060 \\
\hline -..-- & & & \\
\hline 1965 & $\begin{array}{lr}\text { Mar. } & 1,1965 \\
\text { May } & 26,1965 \\
\text { June } & 4,1965\end{array}$ & $\begin{array}{r}10.70 \\
6.06 \\
8.85\end{array}$ & $\begin{array}{r}4,200 \\
1,700 \\
3_{2,680}\end{array}$ \\
\hline 1966 & June 12,1966 & 10.15 & 3,160 \\
\hline 1967 & $\begin{array}{lr}\text { June } & 8,1967 \\
\text { June } & 12,1967\end{array}$ & $\begin{array}{l}6.69 \\
6.92\end{array}$ & $\begin{array}{l}1,950 \\
2,020\end{array}$ \\
\hline 1968 & June 25,1968 & 8.27 & 2,500 \\
\hline
\end{tabular}




\section{Squaw Creek at Ames, Iowa}

\section{Peak stages and discharges-Continued}

\begin{tabular}{|c|c|c|c|}
\hline Water year & Date & $\begin{array}{c}\text { Gage height } \\
\text { (ft) }\end{array}$ & $\begin{array}{c}\text { Discharge } \\
\left(\mathrm{ft}^{3} / \mathrm{s}\right)\end{array}$ \\
\hline 1969 & $\begin{array}{lr}\text { Mar. } & 20,1969 \\
\text { Mar } & 24,1969 \\
\text { June } & 7,1969 \\
\text { June } & 30,1969 \\
\text { July } & 4,1969 \\
\text { July } & 9,1969\end{array}$ & $\begin{array}{c}9.59 \\
7.16 \\
8.34 \\
9.45 \\
\text { (B) } \\
7.84\end{array}$ & $\begin{array}{r}2,970 \\
2,120 \\
2,240 \\
2,580 \\
31,800 \\
2,090\end{array}$ \\
\hline 1970 & May 13,1970 & 10.74 & 3,540 \\
\hline 1971 & Feb. 19,1971 & 10.09 & 3,650 \\
\hline 1972 & Aug. $\quad 2,1972$ & 5.84 & 1,680 \\
\hline 1973 & $\begin{array}{lr}\text { Jan. } & 18,1973 \\
\text { Feb } & 2,1973 \\
\text { Apr. } & 16,1973 \\
\text { May } & 7,1973 \\
\text { Sept. } & 27,1973 \\
\text { Sept. } & 29,1973\end{array}$ & $\begin{array}{r}{ }^{4} 10.80 \\
49.40 \\
8.69 \\
6.65 \\
5.60 \\
6.57\end{array}$ & $\begin{array}{r}{ }^{3} 2,310 \\
{ }^{3} 2,540 \\
2,800 \\
1,950 \\
1,610 \\
1,930\end{array}$ \\
\hline 1974 & $\begin{array}{lr}\text { Oct. } & 12,1973 \\
\text { May } & 16,1974 \\
\text { May } & 18,1974 \\
\text { May } & 22,1974 \\
\text { June } & 9,1974 \\
\text { June } & 19,1974 \\
\text { June } & 22,1974\end{array}$ & $\begin{array}{l}8.64 \\
7.21 \\
8.14 \\
5.75 \\
7.93 \\
8.02 \\
8.95\end{array}$ & $\begin{array}{l}2,750 \\
2,080 \\
2,450 \\
1,620 \\
2,400 \\
2,440 \\
2,900\end{array}$ \\
\hline 1975 & $\begin{array}{ll}\text { Mar. } 20,1975 \\
\text { June } 18,1975 \\
\text { June } 26,1975 \\
\text { June } 27,1975\end{array}$ & $\begin{array}{l}\text { (B) } \\
5.96 \\
9.79 \\
14.00\end{array}$ & $\begin{array}{r}31,700 \\
1,720 \\
3,430 \\
11,300\end{array}$ \\
\hline 1976 & June 14,1976 & 8.55 & 2,680 \\
\hline 1977 & $\begin{array}{l}\text { Aug. } 8,1977 \\
\text { Aug. } 16,1977\end{array}$ & $\begin{array}{l}7.09 \\
8.01\end{array}$ & $\begin{array}{l}2,070 \\
2,430\end{array}$ \\
\hline 1978 & $\begin{array}{l}\text { Apr. } 18,1978 \\
\text { June } 24,1978 \\
\text { Sept. } 14,1978 \\
\text { Sept. } 20,1978\end{array}$ & $\begin{array}{l}7.11 \\
6.33 \\
7.51 \\
5.97\end{array}$ & $\begin{array}{l}2,060 \\
1,840 \\
2,230 \\
1,720\end{array}$ \\
\hline 1979 & $\begin{array}{l}\text { Mar. } 19,1979 \\
\text { Mar. } 23,1979 \\
\text { Mar. } 30,1979 \\
\text { July } 11,1979 \\
\text { Aug. } 10,1979 \\
\text { Aug. } 20,1979\end{array}$ & $\begin{array}{r}11.81 \\
6.28 \\
6.11 \\
6.05 \\
7.88 \\
6.64\end{array}$ & $\begin{array}{l}5,300 \\
1,800 \\
1,740 \\
1,710 \\
2,320 \\
1,890\end{array}$ \\
\hline 1980 & May 30,1980 & 4.69 & 1,250 \\
\hline 1981 & June 24,1981 & 4.26 & 1,060 \\
\hline
\end{tabular}




\section{Squaw Creek at Ames, Iowa}

Peak stages and discharges--Continued

\begin{tabular}{|c|c|c|c|}
\hline Water year & Date & $\begin{array}{c}\text { Gage height } \\
\text { (ft) }\end{array}$ & $\begin{array}{c}\text { Discharge } \\
\left(\mathrm{ft}^{3} / \mathrm{s}\right)\end{array}$ \\
\hline \multirow[t]{5}{*}{1982} & Mar. 19,1982 & 6.61 & 1,900 \\
\hline & May 21,1982 & 5.85 & 1,680 \\
\hline & May 26,1982 & 6.56 & 1,910 \\
\hline & June 16,1982 & 6.78 & 1,970 \\
\hline & July 18,1982 & 10.30 & 3,820 \\
\hline \multirow[t]{9}{*}{1983} & Dec. 28,1982 & 5.88 & 1,690 \\
\hline & Feb. 19,1983 & 5.81 & 1,650 \\
\hline & Feb. 20,1983 & 6.22 & 1,790 \\
\hline & Apr. 1,1983 & 5.76 & 1,620 \\
\hline & Apr. 13,1983 & 7.19 & 2,070 \\
\hline & May 19,1983 & 7.63 & 2,260 \\
\hline & June 29,1983 & 7.20 & 2,070 \\
\hline & July $\quad 2,1983$ & 7.55 & 2,210 \\
\hline & July $\quad 4,1983$ & 7.52 & 2,190 \\
\hline \multirow[t]{4}{*}{1984} & Apr. 30,1984 & 8.40 & 2,590 \\
\hline & May 29,1984 & 8.21 & 2,500 \\
\hline & June 13,1984 & 12.97 & 7,180 \\
\hline & June 17,1984 & 12.77 & 6,820 \\
\hline 1985 & Mar. $\quad 4,1985$ & 6.97 & 2,030 \\
\hline \multirow[t]{2}{*}{1986} & Mar. $\quad 3,1986$ & 5.96 & 1,680 \\
\hline & June 30,1986 & 10.21 & 3,750 \\
\hline \multirow[t]{3}{*}{1987} & Oct. 12,1986 & 7.27 & 2,120 \\
\hline & July 12,1987 & 5.71 & 1,670 \\
\hline & Aug. 26, 1987 & 8.03 & 2,490 \\
\hline 1988 & Feb. 19,1988 & 3.22 & 656 \\
\hline 1989 & May 24, 1989 & 7.01 & 2,050 \\
\hline \multirow[t]{5}{*}{1990} & May 9,1990 & 5.56 & 1,620 \\
\hline & May 19,1990 & 10.61 & 4,200 \\
\hline & May 25,1990 & 9.62 & 3,420 \\
\hline & June 10,1990 & 8.28 & 2,590 \\
\hline & June 17,1990 & 15.97 & 12,500 \\
\hline \multirow[t]{7}{*}{1991} & Mar. 2, 1‘991 & 5.97 & 1,620 \\
\hline & Apr. 12,1991 & 8.90 & 2,730 \\
\hline & Apr. 14,1991 & 8.79 & 2,680 \\
\hline & May 16,1991 & 7.08 & 1,970 \\
\hline & May 18,1991 & 6.64 & 1,830 \\
\hline & May 30, 1991 & 8.56 & 2,570 \\
\hline & June $\quad 4,1991$ & 9.41 & 3,000 \\
\hline 1992 & July 16,1992 & 6.88 & 1,910 \\
\hline
\end{tabular}




\section{Squaw Creek at Ames, Iowa}

Peak stages and discharges-Continued

\begin{tabular}{|c|c|c|c|}
\hline Water year & Date & $\begin{array}{l}\text { Gage height } \\
\text { (ft) }\end{array}$ & $\begin{array}{c}\text { Discharge } \\
\left(\mathrm{ft}^{3} / \mathrm{s}\right)\end{array}$ \\
\hline \multirow[t]{12}{*}{1993} & Mar. 4,1993 & (B) & $5_{2,200}$ \\
\hline & Mar. 7, 1993 & 8.07 & 2,670 \\
\hline & Mar. 30,1993 & 5.84 & 1,800 \\
\hline & June 19,1993 & (B) & 2,740 \\
\hline & June 30,1993 & 9.85 & 3,680 \\
\hline & July $\quad 9,1993$ & 18.54 & 24,300 \\
\hline & July 11,1993 & 13.67 & 8,250 \\
\hline & July 13,1993 & 12.32 & 6,370 \\
\hline & July 17,1993 & 15.01 & 11,000 \\
\hline & Aug. 16,1993 & 13.26 & 7,600 \\
\hline & Aug. 19,1993 & 5.77 & 1,770 \\
\hline & Aug. 29,1993 & 7.68 & 2,510 \\
\hline \multirow[t]{2}{*}{1994} & June 8,1994 & 5.40 & 1,620 \\
\hline & June 24,1994 & 8.66 & 2,920 \\
\hline
\end{tabular}

${ }^{1}$ Historic peak discharge.

${ }^{2}$ Maximum discharge during partial year of record.

${ }^{3}$ Approximate.

${ }^{4}$ Affected by ice.

${ }^{5}$ Discharge due to snowmelt or ice-jam breakup. 


\section{South Skunk River below Squaw Creek near Ames, Iowa}

Location.--Lat $42^{\circ} 00^{\prime} 31^{\prime \prime}$, long $93^{\circ} 35^{\prime} 57^{\prime \prime}$, in SE1/4 NW1/4 sec.13, T.83 N., R.24 W., Story County, Hydrologic Unit 07080105 , on right bank $500 \mathrm{ft}$ downstream from bridge on county highway, $0.2 \mathrm{mi}$ downstream from Squaw Creek, $100 \mathrm{ft}$ upstream from bridge on U.S. Highway 30, 2 mi southeast of Ames, and at mile 222.6 upstream from mouth of Skunk River.

Drainage area.--556 $\mathrm{mi}^{2}$.

Gage.--Water-stage encoder. Datum of gage is $857.10 \mathrm{ft}$ above sea level. Prior to Oct. 1, 1973, at datum $10.00 \mathrm{ft}$ higher. Prior to Oct. 1991, at site $500 \mathrm{ft}$ upstream at same datum.

Stage-discharge relation.--Defined by current-meter measurements.

Bankfull stage.--20 ft.

Remarks.--Base for partial-duration series, $2,500 \mathrm{ft}^{3} / \mathrm{s}$.

\section{Peak stages and discharges}

[ft, feet above gage datum; $\mathrm{ft}^{3} / \mathrm{s}$, cubic feet per second; (B), gage height not determined]

\begin{tabular}{|c|c|c|c|}
\hline Water year & Date & $\begin{array}{l}\text { Gage height } \\
\text { (ft) }\end{array}$ & $\begin{array}{c}\text { Discharge } \\
\left(\mathrm{ft}^{3} / \mathrm{s}\right)\end{array}$ \\
\hline 1944 & May 19, 1944 & 13.00 & ${ }^{1} 10,000$ \\
\hline \multicolumn{4}{|l|}{----- } \\
\hline 1953 & May 1,1953 & 5.47 & 1,620 \\
\hline \multirow[t]{7}{*}{1954} & June 1,1954 & 10.92 & 6,500 \\
\hline & June 11,1954 & 11.92 & 7,980 \\
\hline & June 16,1954 & 7.63 & 3,200 \\
\hline & June 22,1954 & 8.36 & 3,820 \\
\hline & Aug. 22, 1954 & 8.53 & 3,950 \\
\hline & Aug. 26, 1954 & 9.26 & 4,700 \\
\hline & Aug. 28, 1954 & 12.36 & 8,700 \\
\hline \multirow[t]{2}{*}{1955} & Oct. 14,1954 & 6.81 & 2,680 \\
\hline & July 10,1955 & 6.73 & 2,540 \\
\hline 1956 & May 13,1956 & 3.05 & 638 \\
\hline \multirow[t]{2}{*}{1957} & June 16,1957 & 11.58 & 6,360 \\
\hline & July $\quad 4,1957$ & 8.54 & 3,950 \\
\hline \multirow[t]{4}{*}{1958} & June 8,1958 & 6.95 & 2,610 \\
\hline & June 13,1958 & 6.93 & 2,610 \\
\hline & July 2,1958 & 11.13 & 6,120 \\
\hline & July $\quad 4,1958$ & 12.82 & 8,550 \\
\hline \multirow[t]{2}{*}{1959} & Mar. 20, 1959 & 8.69 & 3,860 \\
\hline & May 31,1959 & 10.57 & 5,520 \\
\hline \multirow[t]{2}{*}{1960} & Mar. 30, 1960 & 13.20 & 9,260 \\
\hline & May 7,1960 & 9.47 & 4,600 \\
\hline
\end{tabular}


05471000 South Skunk River below Squaw Creek near Ames, Iowa

Peak stages and discharges-Continued

\begin{tabular}{|c|c|c|c|}
\hline Water year & Date & $\begin{array}{c}\text { Gage height } \\
\text { (ft) }\end{array}$ & $\begin{array}{c}\text { Discharge } \\
\left(\mathrm{ft}^{3} / \mathrm{s}\right)\end{array}$ \\
\hline \multirow[t]{5}{*}{1961} & Feb. 23,1961 & 7.98 & 3,450 \\
\hline & Mar. 15,1961 & 8.05 & 3,380 \\
\hline & June 7,1961 & 7.11 & 2,680 \\
\hline & Aug. 1,1961 & 7.97 & 3,310 \\
\hline & Sept. 30,1961 & 8.27 & 3,520 \\
\hline \multirow[t]{6}{*}{1962} & Mar. 26,1962 & 10.70 & 5,900 \\
\hline & May 8,1962 & 10.47 & 5,140 \\
\hline & May 29,1962 & 9.32 & 4,280 \\
\hline & June 9,1962 & 7.32 & 2,820 \\
\hline & July 15,1962 & 11.87 & 6,330 \\
\hline & July 20,1962 & 7.96 & 3,310 \\
\hline \multirow[t]{2}{*}{1963} & Apr. 29,1963 & 8.56 & 3,520 \\
\hline & May 13,1963 & 10.20 & 4,780 \\
\hline \multirow[t]{2}{*}{1964} & May 8,1964 & 8.84 & 3,600 \\
\hline & June 23,1964 & 9.80 & 4,440 \\
\hline \multirow[t]{5}{*}{1965} & Mar. 1,1965 & 11.87 & 6,410 \\
\hline & Apr. 1,1965 & 11.82 & 6,350 \\
\hline & Apr. 6,1965 & 12.59 & 7,340 \\
\hline & June 5,1965 & (B) & 23,800 \\
\hline & Sept. 20,1965 & 8.36 & 3,720 \\
\hline \multirow[t]{2}{*}{1966} & May 23,1966 & 8.23 & 3,400 \\
\hline & June 12,1966 & 11.45 & 6,380 \\
\hline \multirow[t]{3}{*}{1967} & June $\quad 8,1967$ & 9.90 & 4,960 \\
\hline & June 12,1967 & 8.57 & 3,880 \\
\hline & June 18,1967 & 6.78 & 2,600 \\
\hline \multirow[t]{2}{*}{1968} & June 25,1968 & 12.07 & 7,310 \\
\hline & June 29,1968 & 6.71 & 2,550 \\
\hline \multirow[t]{10}{*}{1969} & Mar. 20, 1969 & 12.15 & 6,620 \\
\hline & Mar. 25, 1969 & (B) & 24,400 \\
\hline & June 7,1969 & 9.22 & 3,920 \\
\hline & June 13,1969 & (B) & ${ }^{2} 2,600$ \\
\hline & June 27,1969 & (B) & 23,600 \\
\hline & June 30,1969 & 11.30 & 5,700 \\
\hline & July $\quad 3,1969$ & 7.80 & 2,890 \\
\hline & July 10,1969 & 11.84 & 6,260 \\
\hline & July 19,1969 & (B) & 23,600 \\
\hline & July 28,1969 & 9.50 & 4,120 \\
\hline 1970 & May 13,1970 & 10.35 & 4,950 \\
\hline \multirow[t]{2}{*}{1971} & Feb. 20,1971 & 12.67 & 8,610 \\
\hline & Mar. 14,1971 & 9.21 & 4,270 \\
\hline \multirow[t]{2}{*}{1972} & Aug. $\quad 2,1972$ & 8.05 & 3,340 \\
\hline & Aug. 8,1972 & (B) & 23,300 \\
\hline
\end{tabular}


05471000 South Skunk River below Squaw Creek near Ames, Iowa

Peak stages and discharges-Continued

\begin{tabular}{|c|c|c|c|}
\hline Water year & Date & $\begin{array}{l}\text { Gage height } \\
\text { (ft) }\end{array}$ & $\begin{array}{c}\text { Discharge } \\
\left(\mathrm{ft}^{3} / \mathrm{s}\right)\end{array}$ \\
\hline \multirow[t]{13}{*}{1973} & Oct. 24,1972 & 7.50 & 2,930 \\
\hline & Nov. 2,1972 & 7.27 & 2,770 \\
\hline & Nov. 7,1972 & 7.73 & 3,090 \\
\hline & Dec. 30,1972 & ${ }^{3} 8.97$ & 23,720 \\
\hline & Jan. 18,1973 & ${ }^{3} 9.91$ & 23,800 \\
\hline & Feb. 2,1973 & ${ }^{3} 12.43$ & 25,120 \\
\hline & Mar. 11,1973 & 8.12 & 3,400 \\
\hline & Mar. 14,1973 & 7.72 & 3,080 \\
\hline & Apr. 16,1973 & 11.94 & 6,860 \\
\hline & May 8,1973 & 10.09 & 5,39 \\
\hline & May 28,1973 & 6.92 & 2,730 \\
\hline & Sept. 27,1973 & 8.89 & 3,530 \\
\hline & Sept. 30,1973 & 9.60 & 3,780 \\
\hline \multirow{9}{*}{1974} & & & \\
\hline & Oct. 10,1973 & 21.69 & 5,880 \\
\hline & Apr. 22,1974 & 18.15 & ${ }^{2} 2,900$ \\
\hline & May 16,1974 & 19.83 & 24,000 \\
\hline & May 18,1974 & 21.13 & 25,100 \\
\hline & May 22,1974 & 18.67 & 23,200 \\
\hline & June 9,1974 & 21.21 & 5,210 \\
\hline & June 19,1974 & 22.58 & 26,900 \\
\hline & June 23,1974 & 23.19 & 7,800 \\
\hline \multirow[t]{4}{*}{1975} & Mar. 20, 1975 & (B) & 23,990 \\
\hline & June 18,1975 & 18.23 & 2,950 \\
\hline & June 22,1975 & 18.76 & 3,240 \\
\hline & June 27,1975 & 25.57 & 14,700 \\
\hline \multirow[t]{4}{*}{1976} & Apr. 18,1976 & 17.75 & 3,170 \\
\hline & Apr. 21,1976 & 16.66 & 2,520 \\
\hline & May 24,1976 & 16.80 & 2,600 \\
\hline & June 14,1976 & 22.14 & 6,410 \\
\hline 1977 & Aug. 16, 1977 & 22.43 & 6,400 \\
\hline \multirow[t]{3}{*}{1978} & Apr. 18,1978 & 20.08 & 4,430 \\
\hline & Sept. 14, 1978 & 19.97 & 4,700 \\
\hline & Sept. 30, 1978 & 18.39 & 3,590 \\
\hline \multirow[t]{9}{*}{1979} & Mar. 19,1979 & 23.68 & 9,430 \\
\hline & Mar. 23, 1979 & 20.17 & 5,160 \\
\hline & Mar. 30, 1979 & 20.55 & 5,470 \\
\hline & June 13,1979 & 16.86 & 2,760 \\
\hline & June 27,1979 & 16.63 & 2,620 \\
\hline & July 11,1979 & 19.48 & 4,500 \\
\hline & July 30,1979 & 17.22 & 2,980 \\
\hline & Aug. 10,1979 & 17.63 & 3,220 \\
\hline & Aug. 20,1979 & 19.24 & 4,330 \\
\hline \multicolumn{4}{|l|}{----- } \\
\hline 1990 & June 17,1990 & ${ }^{4} 25.40$ & 213,000 \\
\hline
\end{tabular}


05471000 South Skunk River below Squaw Creek near Ames, Iowa

Peak stages and discharges--Continued

\begin{tabular}{|c|c|c|c|}
\hline Water year & Date & $\begin{array}{l}\text { Gage height } \\
\text { (ft) }\end{array}$ & $\begin{array}{c}\text { Discharge } \\
\left(\mathrm{tt}^{3} / \mathrm{s}\right)\end{array}$ \\
\hline -...- & - & & -----..- \\
\hline 1992 & $\begin{array}{lr}\text { Mar. } & 6,1992 \\
\text { July } & 6,1992\end{array}$ & $\begin{array}{l}17.62 \\
17.96\end{array}$ & $\begin{array}{r}3,180 \\
23,370\end{array}$ \\
\hline \multirow{16}{*}{1993} & Mar. 31, 1993 & 19.01 & 4,120 \\
\hline & May 11,1993 & 16.85 & 2,740 \\
\hline & June 9,1993 & 18.06 & 3,510 \\
\hline & June 14,1993 & 17.60 & 3,220 \\
\hline & June 19,1993 & 22.32 & 8,030 \\
\hline & June 21, 1993 & 17.31 & 3,060 \\
\hline & July $\quad 1,1993$ & 21.44 & 6,800 \\
\hline & July 9,1993 & ${ }^{4} 25.53$ & 26,500 \\
\hline & July 11,1993 & 23.92 & 14,300 \\
\hline & July 14,1993 & 22.92 & 10,100 \\
\hline & July 17,1993 & 24.20 & 16,100 \\
\hline & Aug. $\quad 1,1993$ & 18.30 & 3,840 \\
\hline & Aug. 10, 1993 & 19.53 & 4,760 \\
\hline & Aug. 17,1993 & 25.25 & 24,200 \\
\hline & Aug. 24, 1993 & 18.33 & 3,980 \\
\hline & Aug. 29, 1993 & 19.20 & 4,570 \\
\hline \multirow[t]{5}{*}{1994} & Mar. $\quad 5,1994$ & 17.68 & 3,400 \\
\hline & June 8,1994 & 17.93 & 3,580 \\
\hline & June 24,1994 & 19.96 & 5,170 \\
\hline & June 30,1994 & 18.20 & 3,760 \\
\hline & July $\quad 1,1994$ & 19.35 & 4,660 \\
\hline
\end{tabular}

${ }^{1}$ Historic peak discharge.

${ }^{2}$ Approximate.

${ }^{3}$ Affected by ice.

${ }^{4}$ Gage height from high-water mark. 


\section{APPENDIX B}

WATER-SURFACE-ELEVATION PROFILES FOR SQUAW CREEK AND THE SOUTH SKUNK RIVER 
26 


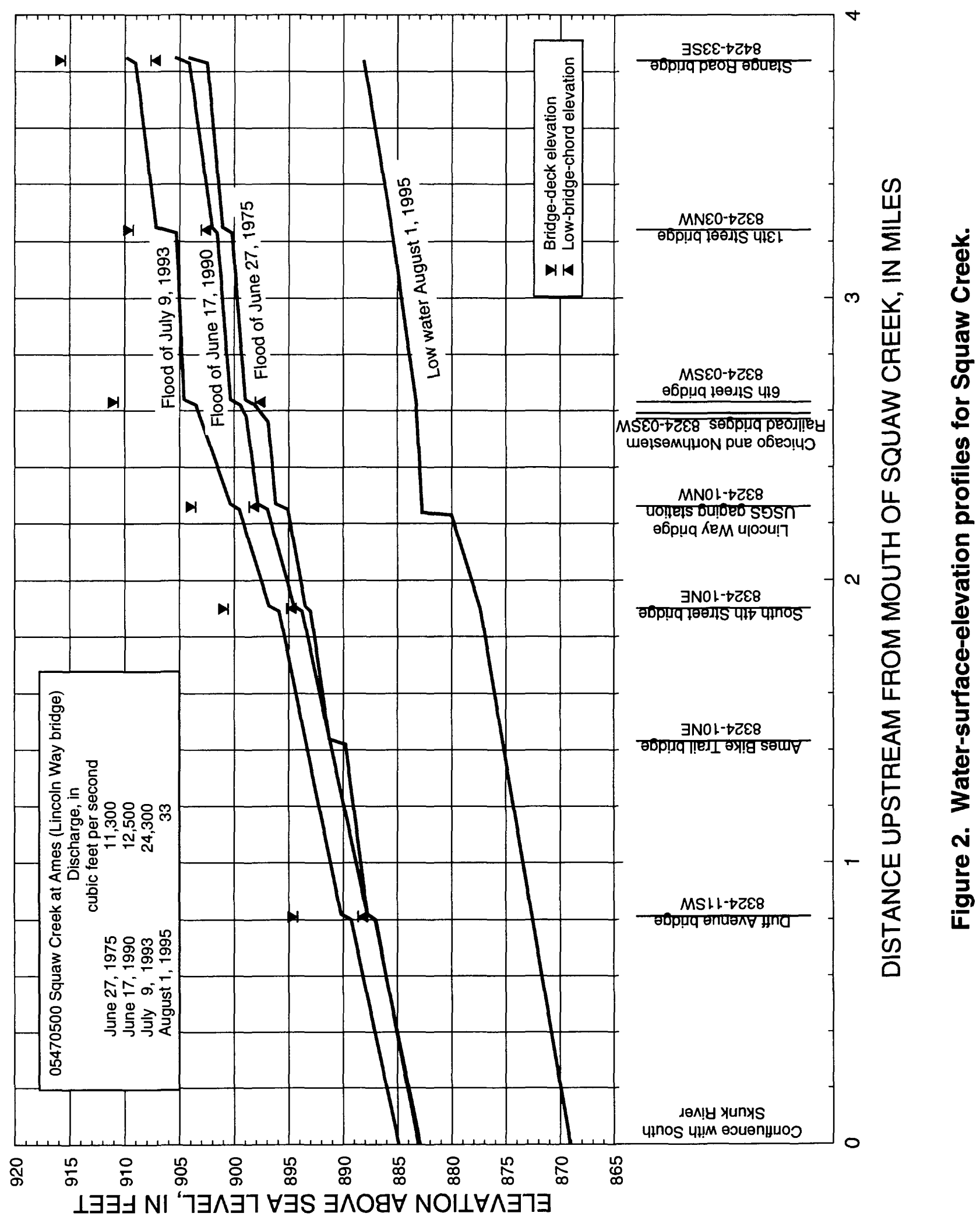




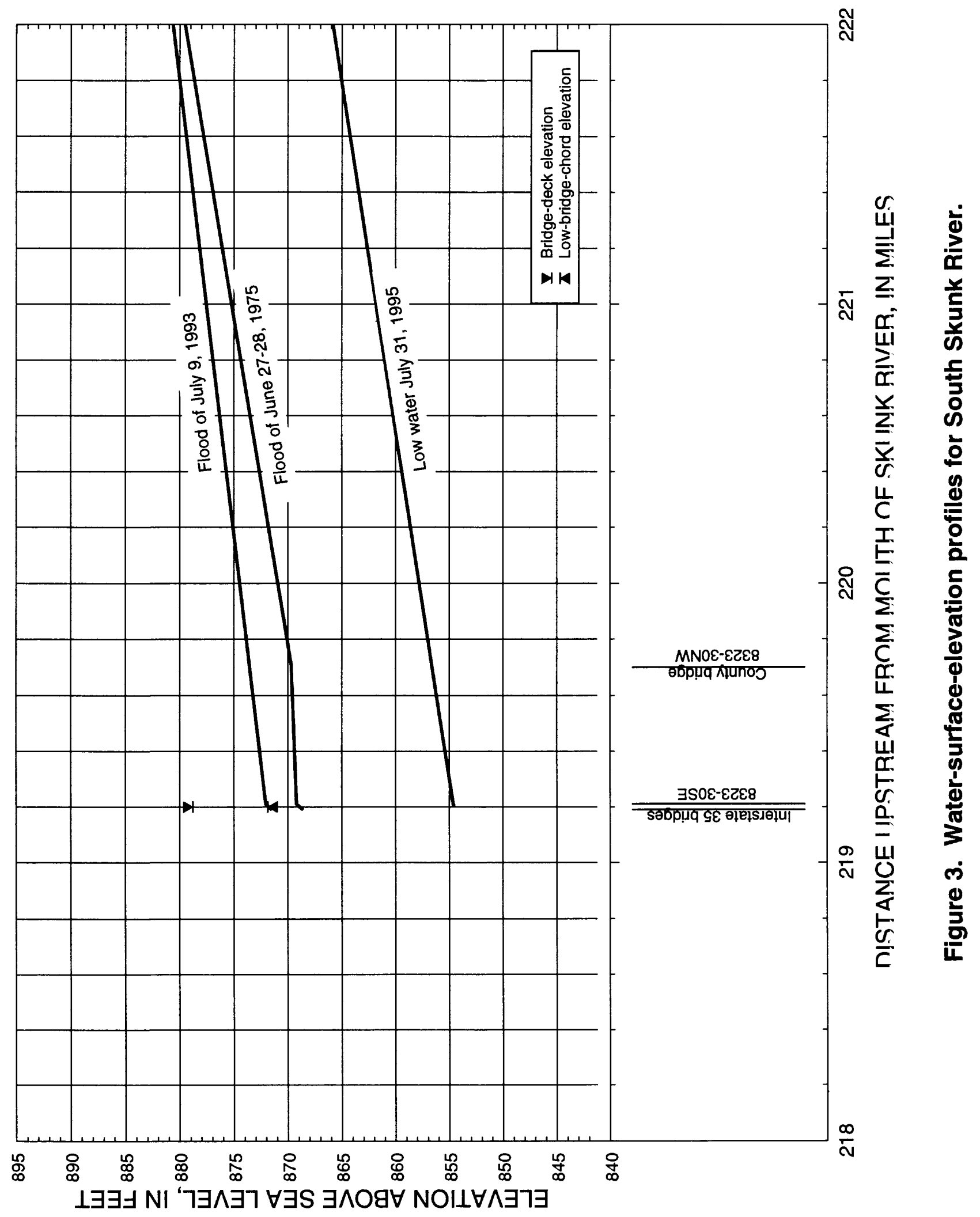




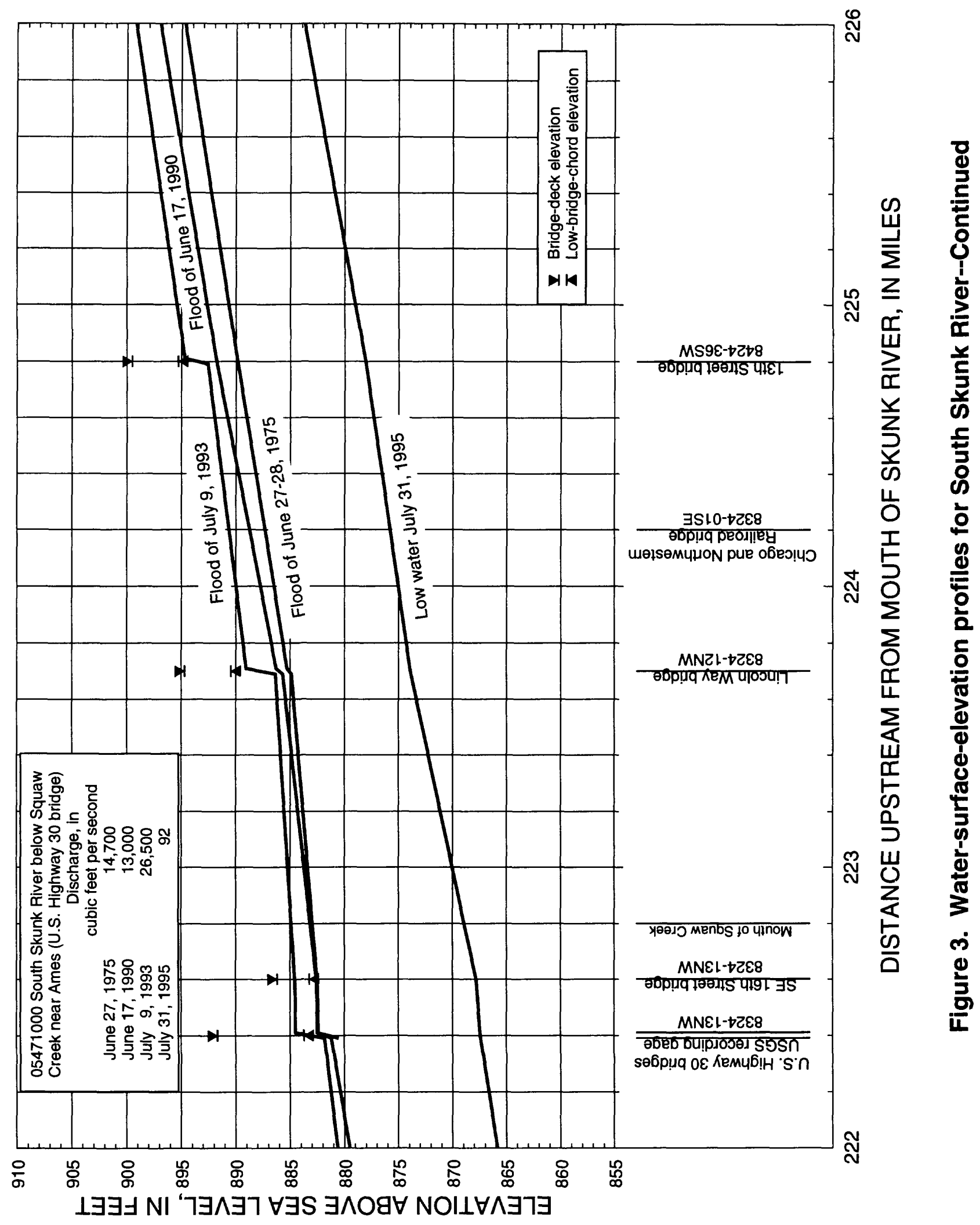




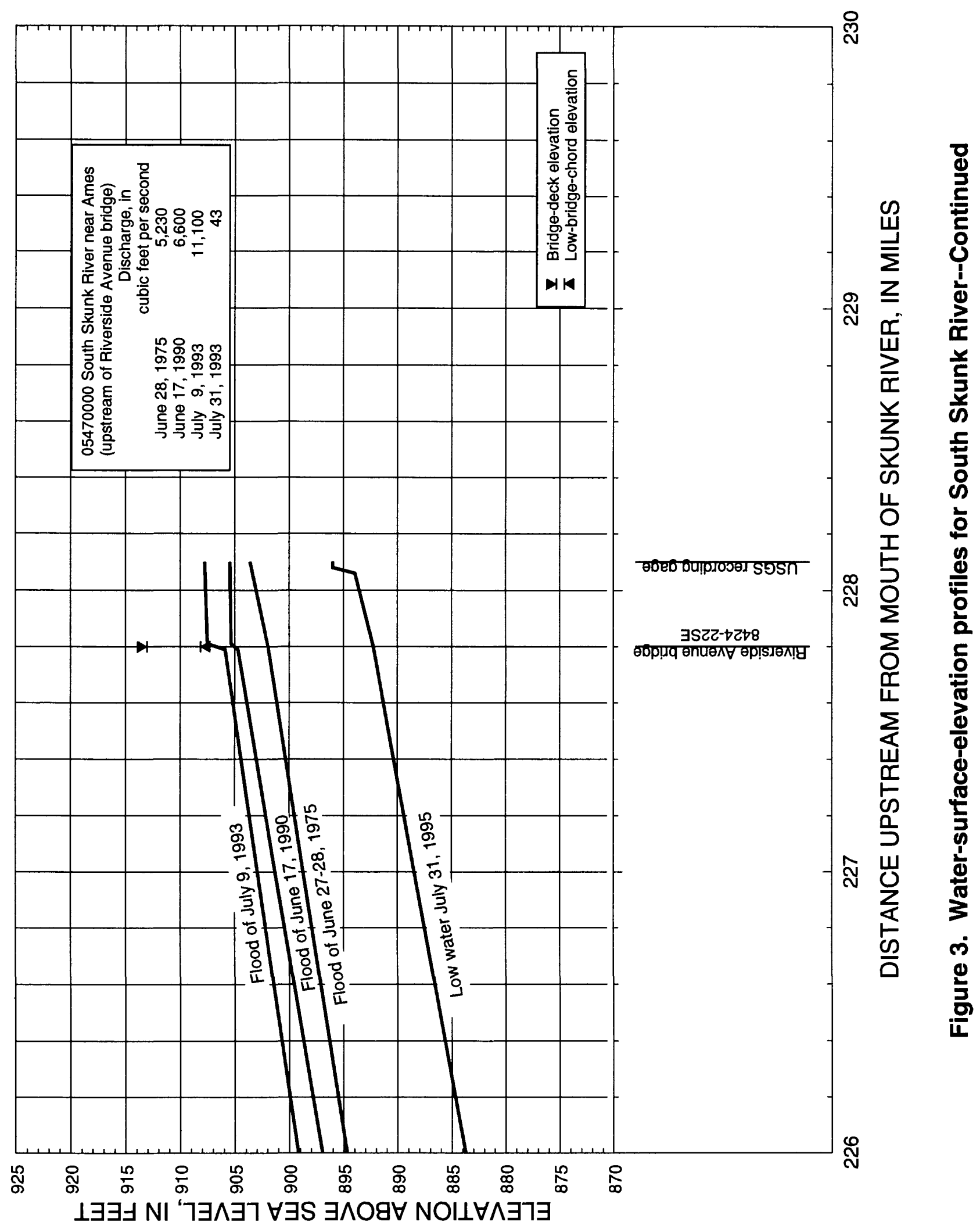




\section{APPENDIX C}

\section{DESCRIPTIONS AND ELEVATIONS OF TEMPORARY BENCH MARKS AND REFERENCE POINTS IN THE SQUAW CREEK AND SOUTH SKUNK RIVER BASINS IN AMES, IOWA, AND VICINITY}

The temporary bench marks listed in this tabulation were established by the U.S. Geological Survey (USGS). Elevations for the bench marks also were established by the USGS except those for which credit is given in the description of the bench mark. The work was done as a part of a stream profile study jointly funded by both the Highway Research Advisory Board and the Project Development Division of the Iowa Department of Transportation, and the USGS.

The stream reaches included in the level work were Squaw Creek and the South Skunk River near Ames. Bench marks were set at the majority of bridges and at intermediate points to preserve the level lines.

Level lines to establish the third-order accuracy bench marks shown herein were surveyed from first- or secondorder bench marks established and adjusted by the National Geodetic Survey (NGS) or the National Mapping Division (NMD) of the USGS. Errors of closure in the USGS level work were adjusted along the level line to the elevations published by the NGS and the NMD. All elevations are referenced to sea level.

The bench marks are identified by an index number, which is composed of the township, range, and section number as mandated by Congress and the quarter section in which they are located. The township and range numbers are combined into a four-digit number, such as 8323 for Township 83 North and Range 23 West. This is followed by a dash and the section number in which the mark is located. Within the section, the quarter in which the mark is located is designated by NE, SE, SW, and NW. A number in parentheses following this letter designation indicates the number of the mark in that particular quarter section. The index number serves to describe the landline location of the mark without further reference in the body of the description.

Standard marks, such as chiseled squares and crosse', were used on concrete or steel. On trees or poles, either a 20-penny pole spike driven horizontally through a short piece of 1/8-in. galvanized pipe or a railroad spike was used. Existing marks were used wherever available, and the agency responsible for the mark, when known, is indicated in the description. Marks indicated as (REFERENCE POINT) following the name of the stream were establishe-1 to permit water-surface elevations to be determined by use of a tape and weight. The terms "right" and "left" in the descriptions are determined as viewed while facing in the direction of the flow of the stream.

The user of this information is cautioned that the bench marks listed herein may be disturbed, destroyed, or may have moved over time. Many of the marks are located on bridges that may have been repaired, replaced, or destroyed since the original level lines were run. It is the responsibility of the user to determine the condition and the suitability of the bench mark.

Additional information can be obtained by writing to the following address: U.S. Geological Survey, Water Resources Division, RM. 269, Federal Building, 400 South Clinton Street, Iowa City, IA 52244. 


\section{TEMPORARY BENCH MARKS AND REFERENCE POINTS}

8323-19 SE--About 4 miles southeast of Ames, in southwest wingwall of county road E57 overpass of I-35, between sections 19 and 30; Iowa Highway Commission plug. (Found 6/94)

Elevation $894.19 \mathrm{ft}$

8323-30 SE (1)-About 4.5 miles southeast of Ames, on downstream I-35 bridge over the South Skunk River, on top of right downstream wingwall; Iowa Highway Commission plug. (Found 7/95)

Elevation $879.53 \mathrm{ft}$

8323-30 SE (2)--About 4.5 miles southeast of Ames, on upstream I-35 bridge over the South Skunk River, on top of left upstream wingwall; Iowa Highway Commission plug. (Found 7/95)

Elevation $879.20 \mathrm{ft}$

8323-30 SE (3)--(REFERENCE POINT) About 4.5 miles southeast of Ames, on downstream I-35 bridge over the South Skunk River, on downstream bridge curb $147 \mathrm{ft}$ streamward of right end of bridge deck; chiseled arrow. (Found 7/95)

Elevation $880.17 \mathrm{ft}$

8323-30 NW (1)--About 4 miles southeast of Ames, on first county road bridge over South Skunk River upstream of $\mathrm{I}-35$, on top of upstream side of left pier; chiseled square.

Elevation $871.87 \mathrm{ft}$

8323-30 NW (2)--(REFERENCE POINT) About 4 miles southeast of Ames, on first county road bridge over the South Skunk River upstream of I-35, on top of downstream guardrail just right of bridge center; filed arrow.

Elevation $877.91 \mathrm{ft}$

8323-32 SE (1)--About 6 miles southeast of Ames, on the first bridge over the South Skunk River downstream of $\mathrm{I}-35$, on upstream end of $1 \mathrm{ft}$ by $1 \mathrm{ft}$ beam adjacent to the left abutment, on top of $1 / 2$ in. diameter rod; chiseled cross.

Elevation $862.80 \mathrm{ft}$

8323-32 SE (2)--(REFERENCE POINT) About 6 miles southeast of Ames, on the first bridge over the South Skunk River downstream of I-35, on left downstream side of first vertical member left of center of left truss; filed arrow.

Elevation $868.85 \mathrm{ft}$
8323-32 SE (3)--About 6 miles southeast of Ames, on the first bridge over the South Skunk River downstream of I-35, on upstream end of bridge pier; a chiseled cros (set by Iowa Natural Resources Council).

Elevation 862.85 ft

8324-03 SW (1)--At Ames, at 6th Street bridge over Squew Creek, on top of right downstream wingwall; chiseled square. (Found 7/95)

Elevation $908.41 \mathrm{ft}$

8324-03 SW (2)--(REFERENCE POINT) At Ames, at $6 t^{\text {th }}$ Street bridge over Squaw Creek, on downstream handrail at 9 th post from left end of bridge; chiseled arrow. (Found 7/95)

Elevation $916.0 \varepsilon \mathrm{ft}$

8324-03 NW (1)--At Ames, at 13th Street bridge over Squaw Creek, on top of wingpost at right downstrean end of bridge; Iowa Highway Commission plug. (Found 7/95)

Elevation $912.44 \mathrm{ft}$

8324-03 NW (2)--(REFERENCE POINT) At Ames, at 13 th Street bridge over Squaw Creek, on downstream handrail post, 15th post from right end of bridge; chiseled arrow. (Found 7/95)

Elevation $912.3 \% \mathrm{ft}$

8324-10 NE (1)--At Ames, at 4th Street bridge over Squiw Creek, at left upstream end of bridge, on top of curb: chiseled square. (Found 7/95)

Elevation $900.68 \mathrm{ft}$

8324-10 NE (2)--(REFERENCE POINT) At Ames, at 4th Street bridge over Squaw Creek, at downstream handrail, on 12th post from left abutment; chiseled arrow. (Found 7/95)

Elevation $903.0 \Omega \mathrm{ft}$

8324-10 NW (1)--At Ames, at Lincoln Way bridge over Squaw Creek, on top of left downstream wingwall; chiseled square. (Found 6/94)

Elevation $903.54 \mathrm{ft}$

8324-10 NW (2)--At Ames, at Lincoln Way bridge over Squaw Creek, on top of right downstream wingwall: Iowa Highway Commission plug. (Found 6/94)

Elevation $903.34 \mathrm{ft}$

8324-11 SW--At Ames, at South Duff Avenue bridge over Squaw Creek, at left upstream end of bridge, on top of wingpost; chiseled square. (Found 7/95)

Elevation 897.0? $\mathrm{ft}$ 
8324-11 SE--(REFERENCE POINT) At Ames, at South Duff Avenue bridge over Squaw Creek, at base of light pole in center of bridge on downstream side of bridge; top of $1 / 4$ inch bolt. (Found 7/95)

Elevation $894.17 \mathrm{ft}$

8324-12 NW (1)--At Ames, at Lincoln Way bridge over South Skunk River, on top of wingpost at left downstream end of bridge; Iowa Highway Commission plug. (Found 7/95)

Elevation $897.11 \mathrm{ft}$

8324-12 NW (2)--(REFERENCE POINT) At Ames, at Lincoln Way bridge over South Skunk River, $110 \mathrm{ft}$ streamward of left upstream end of bridge on concrete deck upstream of the guardrail; chiseled square. (Found 7/95)

Elevation $894.95 \mathrm{ft}$

8324-13 NW (1)--About 2 miles southeast of Ames, on Highway 30 bridge over the South Skunk River, on right downstream curb; Iowa Highway Commission plug. (Found 7/95)

Elevation $891.40 \mathrm{ft}$

8324-13 NW (2)--About 2 miles southeast of Ames at SE 16th Street bridge over South Skunk River, downstream of mouth of Squaw Creek, on upstream $1 \mathrm{ft}$ by $1 \mathrm{ft}$ pile cap, in top of vertical bolt; a chiseled cross (RM 6). (Found 7/93)

Elevation $882.78 \mathrm{ft}$

8324-14 NE--About 2.5 miles southeast of Ames, at the southeast corner of the intersection of Highway 69 and Airport Road, on top of the northeast corner of the concrete foundation for traffic light controls; a chiseled square.

Elevation $903.72 \mathrm{ft}$

8324-24 NE--About 3.5 miles southeast of Ames, on gravel road bridge over South Skunk River, at right upstream end of truss, on top of anchor bolt; filed cross.

Elevation $874.22 \mathrm{ft}$

8324-24 SE--(REFERENCE POINT) About 3.5 miles southeast of Ames, on gravel road bridge over South Skunk River, on top of downstream tiebar, $1 \mathrm{ft}$ right of center of truss; filed arrow.

Elevation $876.22 \mathrm{ft}$
8324-24 SW--About 3.75 miles southeast of Ames, near southwest corner of sec. 24 , just north of entrance to farmhouse east, on east headwall of concrete culvert; chiseled square.

Elevation 9?7.07 ft

8324-25 NW (1)--About 4.25 miles southeast of Ames, about $300 \mathrm{ft}$ north of intersection of two county' roads, on top center of east headwall of concrete culvert; chiseled square.

Elevation $923.49 \mathrm{ft}$

8324-25 NW (2)--About 4.5 miles southeast of Ames, 0.3 miles east of intersection of two county roats, on top center of south headwall of concrete culvert; chiseled square.

Elevation $8 \mathbf{1}^{\wedge .22 \mathrm{ft}}$

8424-22 SE (1)--About 3 miles northeast of Ames, at Riverside Road bridge over South Skunk River, on top of guardrail at right upstream end of bridge; Iowa Highway Commission plug. (Found 7/95)

Elevation $9 * 4.52 \mathrm{ft}$

8424-22 SE (2)--(REFERENCE POINT) About 3 miles northeast of Ames, at Riverside Road bridge over South Skunk River, on upstream guardrail $75 \mathrm{ft}$ stream 'vard of the Iowa Highway Commission plug; chiseled square. (Found 7/95)

Elevation $915.24 \mathrm{ft}$

8424-33 SE (1)--At Ames, at Stange Road bridge over Squaw Creek, on top of bolt at left upstream ent of bridge, at left end of handrail; chiseled cross. (Found 7/95)

\section{Elevation $912.56 \mathrm{ft}$}

8424-33 SE (2)--(REFERENCE POINT) At Ames, at Stange Road bridge over Squaw Creek, at dowrstream side of bridge, on walk at center of bridge; chis sled cross. (Found 7/95)

Elevation $915.82 \mathrm{ft}$

8424-36 SW (1)--At Ames, at 13th Street bridge ove- South Skunk River, on top of wingpost at left upstrear end of bridge; chiseled square. (Found 7/95)

Elevation $9^{` 3} 3.94 \mathrm{ft}$

8424-36 SW (2)--(REFERENCE POINT) At Ames, at 13th Street bridge over South Skunk River, center of 7 th vertical handrail support on upstream side of bridge; chiseled arrow. (Established 6/93)

Elevation $9^{\mathfrak{3}} 3.20 \mathrm{ft}$ 